University of Nebraska - Lincoln

DigitalCommons@University of Nebraska - Lincoln

Papers in the Earth and Atmospheric Sciences

Earth and Atmospheric Sciences, Department

2010

\title{
Centennial eolian cyclicity in the Great Plains, USA: a dominant climate pattern of wind transport over the past 4000 years?
}

Antje Schwalb

Technische Universität Braunschweig, antje.schwalb@tu-bs.de

Walter E. Dean

U.S. Geological Survey, Denver, CO, dean@usgs.gov

Sherilyn C. Fritz

University of Nebraska-Lincoln, sfritz2@unl.edu

Christoph E. Geiss

Trinity College, Hartford, CT, christoph.geiss@trincoll.edu

Bernd Kromer

Universität Heidelberg, bernd.kromer@iup.uni-heidelberg.de

Follow this and additional works at: https://digitalcommons.unl.edu/geosciencefacpub

Part of the Earth Sciences Commons

Schwalb, Antje; Dean, Walter E.; Fritz, Sherilyn C.; Geiss, Christoph E.; and Kromer, Bernd, "Centennial eolian cyclicity in the Great Plains, USA: a dominant climate pattern of wind transport over the past 4000 years?" (2010). Papers in the Earth and Atmospheric Sciences. 120.

https://digitalcommons.unl.edu/geosciencefacpub/120

This Article is brought to you for free and open access by the Earth and Atmospheric Sciences, Department of at DigitalCommons@University of Nebraska - Lincoln. It has been accepted for inclusion in Papers in the Earth and Atmospheric Sciences by an authorized administrator of DigitalCommons@University of Nebraska - Lincoln. 


\title{
Centennial eolian cyclicity in the Great Plains, USA: a dominant climate pattern of wind transport over the past 4000 years?
}

\author{
Antje Schwalb ${ }^{\mathrm{a}, *}$, Walter E. Dean ${ }^{\mathrm{b}}$, Sherilyn C. Fritz ${ }^{\mathrm{c}}$, Christoph E. Geiss $^{\mathrm{d}}$, Bernd Kromer ${ }^{\mathrm{e}}$ \\ a Institut für Umweltgeologie, Technische Universität Braunschweig, Langer Kamp 19c, D-38106 Braunschweig, Germany \\ ${ }^{\mathrm{b}}$ U.S. Geological Survey, Box 25046, MS 980, Federal Center, Denver, CO, USA \\ ${ }^{\mathrm{c}}$ Department of Geosciences, University of Nebraska - Lincoln, Lincoln, NE 68588-0340, USA \\ d Department of Physics, Trinity College, 300 Summit Street, Hartford, CT 06106, USA \\ ${ }^{\mathrm{e}}$ Heidelberger Akademie der Wissenschaften, Institut für Umweltphysik, Universität Heidelberg, INF 229, D-69120 Heidelberg, Germany
}

\section{A R T I C L E I N F O}

\section{Article history:}

Received 3 October 2009

Received in revised form

24 May 2010

Accepted 4 June 2010

\begin{abstract}
A B S T R A C T
Proxy evidence at decadal resolution from Late Holocene sediments from Pickerel Lake, northeastern South Dakota, shows distinct centennial cycles (400-700 years) in magnetic susceptibility; contents of carbonate, organic carbon, and major elements; abundance in ostracodes; and $\delta^{18} \mathrm{O}$ and $\delta^{13} \mathrm{C}$ values in calcite. Proxies indicate cyclic changes in eolian input, productivity, and temperature. Maxima in magnetic susceptibility are accompanied by maxima in aluminum and iron mass accumulation rates (MARs), and in abundances of the ostracode Fabaeformiscandona rawsoni. This indicates variable windy, and dry conditions with westerly wind dominance, including during the Medieval Climate Anomaly. Maxima in carbonates, organic carbon, phosphorous, and high $\delta^{13} \mathrm{C}$ values of endogenic calcite indicate moister and less windy periods with increased lake productivity, including during the Little Ice Age, and alternate with maxima of eolian transport. Times of the Maunder, Spörer and Wolf sunspot minima are characterized by maxima in $\delta^{18} \mathrm{O}$ values and aluminum MARs, and minima in $\delta^{13} \mathrm{C}$ values and organic carbon content. We interpret these lake conditions during sunspot minima to indicate decreases in lake surface water temperatures of up to $4-5^{\circ} \mathrm{C}$ associated with decreases in epilimnetic productivity during summer.

We propose that the centennial cycles are triggered by solar activity, originate in the tropical Pacific, and their onset during the Late Holocene is associated with insolation conditions driven by precession. The cyclic pattern is transmitted from the tropical Pacific into the atmosphere and transported by westerly winds into the North Atlantic realm where they strengthen the Atlantic Meridional Overturning Circulation during periods of northern Great Plains wind maxima. This consequently leads to moister climates in Central and Northern Europe. Thus, Pickerel Lake provides evidence for mechanisms of teleconnections including an atmospheric link bridging between the different climate regimes from the tropical Pacific to the North Atlantic and onto the European continent.
\end{abstract}

(c) 2010 Elsevier Ltd. All rights reserved.

\section{Introduction}

Paleoclimatic records of many regions indicate that the droughts of the 20th century were relatively minor compared with those in the past, which opens up the possibility that future droughts may be much greater in length or magnitude (Overpeck and Webb, 2000). In the Great Plains of the U.S., which is a major agricultural region, most of the published records of droughts span the

\footnotetext{
* Corresponding author. Tel.: +49 531391 7241; fax: +49 5313918130.

E-mail addresses: antje.schwalb@tu-bs.de (A. Schwalb), dean@usgs.gov (W.E. Dean), sfritz2@unl.edu (S.C. Fritz), christoph.geiss@trincoll.edu (C.E. Geiss), bernd.kromer@iup.uni-heidelberg.de (B. Kromer).
}

past 1000-2000 years (e.g., Muhs et al., 1997; Woodhouse and Overpeck, 1998; Fritz et al., 2000; Laird et al., 1996a, 2003; Fye et al., 2003; Cook et al., 2004; Graham et al., 2007; Forman et al., 2008; Seifert et al., 2009), although a few high-resolution records extend to earlier periods of the Holocene, such as the those published by Brown et al. (2005), Clark et al. (2002), and Donovan and Grimm (2007).

In the north-central USA, an early Holocene increase in aridity is evident in the east- and northward expansion of prairie (Whitlock et al., 1993). The mid-Holocene was drier than today (Dean et al., 1996; Fritz et al., 2001; Smith et al., 2002), and after 4 cal. kyr BP, rising ground water levels and the west- and southward expansion of forest indicates a return to moister conditions (Wright, 1976; Bradbury et al., 1993; Bradbury and Dieterich-Rurup, 1993; 
Whitlock et al., 1993; Schwalb et al., 1995). The timing, magnitude and duration of Holocene droughts and pluvials, however, varied considerably in space and time (Meltzer, 1999; Fritz et al., 2000, 2001). Both the Medieval Climate Anomaly (MCA) and the Little Ice Age (LIA) are considered to have been hydrologically complex, and there is no clear evidence to suggest that either interval was coherent or unusual in effective moisture relative to long-term patterns (Fritz et al., 2000). Differences among sites in the timing of hydrological events indicate that the biotic and geochemical response of the lakes to climate variations is mediated by their hydrologic systems (Donovan et al., 2002; Smith et al., 2002). The response may be heterogeneous spatially and contrasting information from geochemical and biotic proxies from the same paleorecord can occur (Schwalb and Dean, 2002). This shows the need for (i) a multi-proxy approach and (ii) the application of proxies that are less affected by catchment and lake system dynamics, as well as diagenetic transformations in the sediments (e.g., aluminum and titanium). To accomplish these goals, we have selected a set of multi-proxy data from lake sediments that reflect both processes in the catchment, as well as in the lake system itself. Pickerel Lake, Day County, South Dakota (Fig. 1) is characterized by high sedimentation rates of approximately $0.15 \mathrm{~cm} \mathrm{yr}^{-1}$, and provides a high-resolution climate and environmental record. Cyclic patterns of magnetic susceptibility and other proxy data are present in the upper $6 \mathrm{~m}$ of a 17.7-m-long core (Fig. 2). We evaluate whether these cycles represent a climatic signature by analysis of the geochemical composition of the sediment, as well as the composition of ostracode species assemblages. These proxies suggest variability in eolian transport and hydrology in the climate of north-central North America. We also review evidence from other proxy records during the Late Holocene in order to assess potential causes of climate variability in North America and their teleconnections with other geographic areas. These data contribute to discussions about century-scale hydrologic variability and its possible cyclicity (e.g., Verschuren and Charman, 2008; Wanner et al., 2008).

\section{Regional setting}

Pickerel Lake is located at the intersection of several different climatic zones in the north-central United States (Fig. $1 \mathrm{~A}$ ). The seasonal movement of the Intertropical Convergence Zone (ITCZ) leads to a northward extension of subtropical moisture from the Gulf of Mexico during the northern hemisphere summer (Fig. $1 \mathrm{~A}$, Bryson and Hare, 1974; Anderson, 1993). During northern winter, the region is influenced by extratropical westerly circulation associated with a southward displacement of the ITCZ and strengthening of the Aleutian Low in the eastern North Pacific. Additionally, Arctic high pressure systems shift the polar front to the south over the Great Plains (GP) of the US. Periods of drought in the GP reflect an interplay of these varied airmasses, as influenced by sea-surface temperatures in both the Pacific and Atlantic Oceans (e.g., Cole et al., 2002; McCabe et al., 2004; MacDonald and Case, 2005; Seager et al., 2005; McCabe and Palecki, 2006; Herweijer et al., 2007).

Sediments from Pickerel Lake (Fig. 1B), have been used to reconstruct the past history of vegetation and climate (Watts and Bright, 1968; Stuiver, 1970; Haworth, 1972; Smith, 1991; Schwalb and Dean, 1998; Dean and Schwalb, 2000). Because surface water input by intermittent streams is extremely low, Pickerel Lake does not receive much detrital sediment through riverine input. Pickerel Lake is a $\mathrm{MgCaHCO}_{3} \mathrm{SO}_{4}$ lake, with a specific conductance of $450 \mu \mathrm{S} \mathrm{cm}^{-1}$. The low total ionic concentration and major ion chemistry indicate that the lake is probably a ground water flow-
A

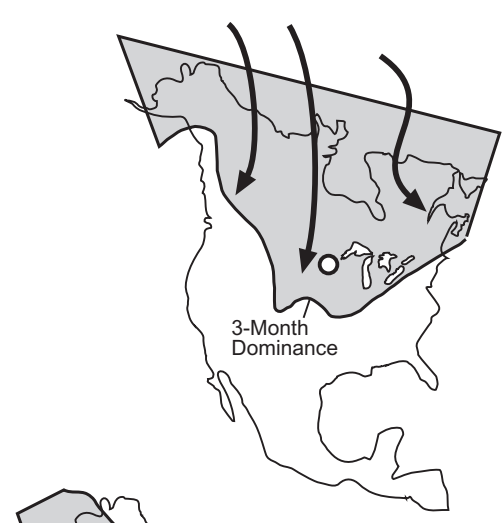

B

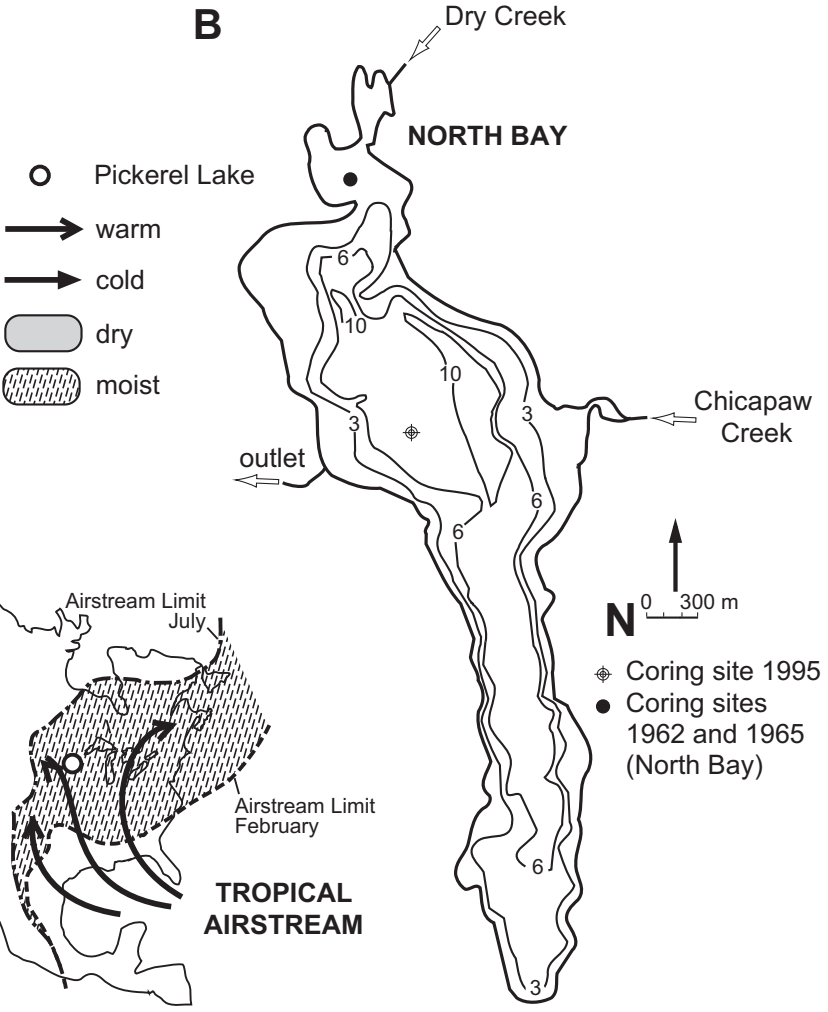

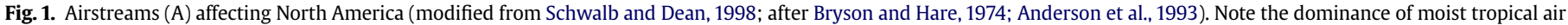

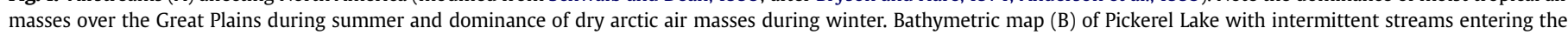
lake, outflowing stream, and core site (modified from Schwalb and Dean, 1998). Contour interval is $3 \mathrm{~m}$ plus $10 \mathrm{~m}$. 


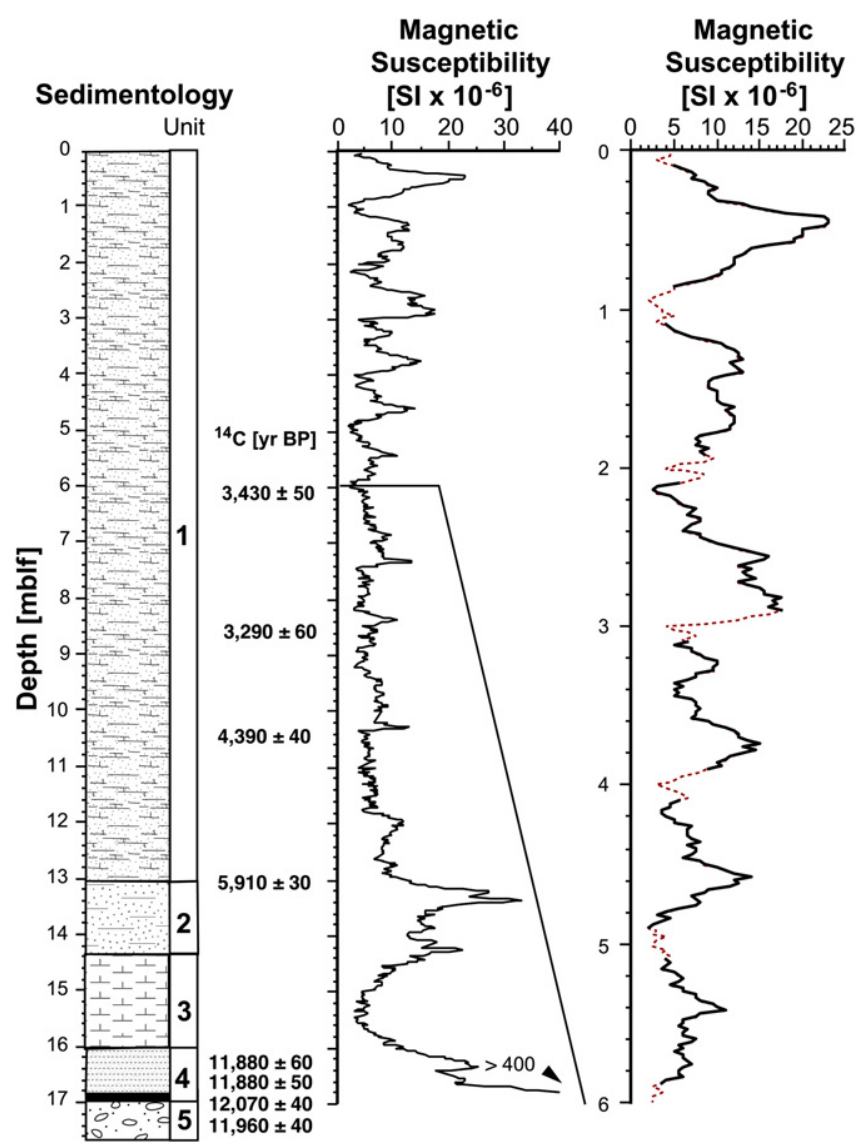

Fig. 2. Sedimentology, raw radiocarbon dates, and magnetic susceptibility for the $17 \mathrm{~m}$ core from Pickerel Lake. Sediment Units 1 and 3: calcareous clayey silt; Unit 2: calcareous sandy silt; Unit 4: clayey silt with laminated sections and debris at the base; Unit 5: gravel and sand. Calibrated radiocarbon ages for the upper $6 \mathrm{~m}$ are shown in Table 1 and Fig. 3. Uncalibrated radiocarbon ages below $6 \mathrm{~m}$ are from Dean and Schwalb (2000). Note the lack of cycles in magnetic susceptibility below $6 \mathrm{~m}$ in the $17 \mathrm{~m}$ core. Cycles in magnetic susceptibility in the upper $6 \mathrm{~m}$ of core are expanded at the right. Dashed sections denote possible edge effects at core tops and ends.

through system (Smith, 1991), such that the lake gains water from ground water inflow and loses water via discharging into the local ground water flow system. Fluctuations in ground water levels cause the lake level to vary by as much as $1 \mathrm{~m}$ seasonally. During the drought of the 1930s, for example, the lake level was $2 \mathrm{~m}$ below the outlet, and North Bay was almost dry (Watts and Bright, 1968). Because the lake is well mixed by wind, the maximum difference between temperatures of surface water and subsurface water is $5{ }^{\circ} \mathrm{C}$ in summer, and changes in surface water temperature closely follow those in air temperature (Niehus et al., 1999).

For the past approximately 8000 years, the dominant vegetation around Pickerel Lake has been prairie (Watts and Bright, 1968), and during that period, changes recorded in the sediments are not likely associated with major changes in catchment vegetation in the catchment in contrast to, for example, Elk Lake, Minnesota, where vegetation switched from forested to prairie and back again (Bradbury et al., 1993). In addition, a significant anthropogenic impact on sedimentation in Pickerel Lake prior to 1890 can be excluded, because there were no major population centers. Thus, detrital sediments archived in Pickerel Lake are mainly of eolian origin. This allows us to provide a history of wind activity for the Late Holocene by using a series of proxy indicators, such as magnetic susceptibility, iron and aluminum mass accumulation rates (MAR) that are direct proxies of wind activity. Other proxies, such as organic carbon (OC), carbonate, stable isotopes and species assemblages of ostracodes provide information about external forcings and internal lake system dynamics.

\section{Materials and methods}

We conducted a high-resolution (decadal) study of the upper $6 \mathrm{~m}$ of sediment from a $17.7-\mathrm{m}$-long core. The core was taken in 1995 from the ice surface in a water depth of $8.4 \mathrm{~m}$ using a modified Livingstone piston corer $5 \mathrm{~cm}$ in diameter (Wright, 1967). The upper $6 \mathrm{~m}$ of the core are characterized by cyclic variations in magnetic susceptibility (Fig. 2; Schwalb and Dean, 1998; Dean and Schwalb, 2000) which were augmented in this study by analyses of total carbon (TC); total inorganic carbon (IC); major, minor, and trace elements; ostracode species assemblages; and stable carbon and oxygen analysis of bulk sediment samples on a higher resolution data set.

Whole-core magnetic susceptibility $(\kappa)$ was measured at LacCore, Limnological Research Center, University of Minnesota, using a Bartington MS2C loop sensor with a loop diameter of $10 \mathrm{~cm}$, which averages over an approximately $20 \mathrm{~cm}$ long core segment, and removes the sensor drift from the measured value (A. Noren, personal communication, 2010). Susceptibility results in standard units, SI, are given in $10^{-6}$. The data was not subjected to a deconvolution routine and is therefore smoothed and affected by edge effects at the beginning and end of each 1-m core segment. Susceptibility measurements were made at 2-cm intervals (total of 298 measurements). To account for possible edge effects we marked the sections encompassing the first and last five measurements of each core segment as dashed lines in Fig. 2. Comparisons with susceptibility measurements conducted on individual samples from a Kullenberg core taken in 2004, which are neither smoothed nor affected by edge effects (Geiss, unpublished data), confirm that the observed cyclical variations in $\kappa$ shown in Fig. 2 are not due to measurement artefacts. Thus, in Figs. 5-7 we show the entire magnetic susceptibility data set including core tops and ends.

Samples collected at $10-\mathrm{cm}$ intervals (total of 60 samples) were used to measure the percentages of organic matter and $\mathrm{CaCO}_{3}$ by loss on ignition (LOI; Schwalb and Dean, 1998; Dean and Schwalb, 2000) at the Limnological Research Center. The LOI method also provides a measure of dry bulk density (DBD) used in calculating sediment mass accumulation rates (MAR, see below). Dried and powdered samples (total: 286) collected at 2-cm intervals were analyzed for weight percentages of TC and IC by coulometric titration of carbon-dioxide following extraction from the sediment by combustion at $950{ }^{\circ} \mathrm{C}$ and acid volatilization, respectively (Engleman et al., 1985) in USGS laboratories, Denver. Percent OC was calculated as the difference (TC - TIC), and percent $\mathrm{CaCO}_{3}$ was calculated as $\mathrm{CaCO}_{3}=\mathrm{IC} / 0.12$, where 0.12 is the fraction of carbon in $\mathrm{CaCO}_{3}$. Accuracy and precision of this method usually are better than $0.10 \mathrm{wt} \%$ for TC and TIC. Samples collected at 4-cm intervals (total of 150 samples) were analyzed for major, minor, and trace elements by inductively coupled, argon-plasma, emission spectrometry (ICP-AES; Briggs, 2002) in USGS laboratories, Denver, Colorado. Rock standards (USGS) were included with the sediment samples, and $10 \%$ of the samples were duplicated. The precision, determined by analyzing rock standards and duplicate sediment samples, is better than $10 \%$.

Ostracode valves were separated from 2-cm-thick slices, representing approximately 10-20 years of deposition, taken every $4 \mathrm{~cm}$. Samples of up to $25 \mathrm{~g}$ wet sediment were processed according to Schwalb and Dean (1998). In total, 145 samples containing up to 140 valves each, were analyzed. Not all samples yielded ostracodes. Overall, 12 species were identified (Schwalb and Dean, 1998). Results are expressed in number of ostracode valves per gram wet sediment. 
Splits of bulk sediment from the carbon analyses were roasted in vacuum for $1 \mathrm{~h}$ at $380 \pm 10^{\circ} \mathrm{C}$ to remove volatile organic carbon prior to isotopic analyses. $\mathrm{CO}_{2}$ was liberated from each sample using a Finnigan Kiel automated carbonate extraction device and analyzed in line with an isotope-ratio mass spectrometer. In the Kiel device, four drops of $100 \%$ phosphoric acid were dripped on each sample in individual reaction vessels and allowed to react at $75 \pm 1{ }^{\circ} \mathrm{C}$ to completion in $10 \mathrm{~min}$ (Dean and Schwalb, 2000). Samples are reported in the usual per mil $(\%) \delta$-notation relative to the VPDB (Vienna Pee Dee Belemnite) standard for carbon and oxygen:

$\delta \%_{0}=\left[\left(R_{\text {sample }} R_{V P D B}\right)-1\right]$

$\times 10^{3}$, where $\mathrm{R}$ is the $\operatorname{ratio}(C / C) \operatorname{or}(O / O)$.

Bulk sediment mass accumulation rates (MAR, in $\mathrm{g} \mathrm{cm}^{-2} \mathrm{yr}^{-1}$ ) were calculated as the product of the dry bulk density (DBD, in $\left.\mathrm{g} \mathrm{cm}^{-3}\right)$ and the sedimentation rate $\left(0.15 \mathrm{~cm} \mathrm{yr}^{-1}\right)$. Sediment component MARs were calculated as the product of the fraction of each component and the bulk sediment MAR. In this paper, the MARs for sediment components are expressed in units of $\mathrm{g} \mathrm{m}^{-2} \mathrm{yr}^{1}$.

\section{Results}

The upper $6 \mathrm{~m}$ of sediment from the Pickerel Lake sediment record consist of a massive, olive-gray to olive-gray-brown, calcareous, clayey silt with varying amounts of fine sand (Fig. 2) and ostracode valves. This section, representing the past approximately 4000 years, is marked by distinct cycles in magnetic susceptibility well above levels in the lower part of unit 1 (Fig. 2). The amplitudes of these cycles increase towards the top of the core. Here we present, in addition to the magnetic susceptibility data, data from eight other proxies in different units, including mass accumulation rates (MAR), abundances, percentages and per mil, all displaying a cyclic behavior, and thus underlining the environmental signature archived in the magnetic susceptibility record.

\subsection{Chronostratigraphy}

The chronostratigraphy for the upper $6 \mathrm{~m}$ of the 1995 Pickerel Lake core is provided by seven AMS ${ }^{14} \mathrm{C}$ dates on bulk organic carbon and four AMS ${ }^{14} \mathrm{C}$ dates on picked charcoal (Table 1). As an additional dated horizon, we use the increase in lead $(\mathrm{Pb})$ at 20 cmblf (unpublished data) taken as AD 1890 (D. Engstrom, personal communication, 1995). The ${ }^{14} \mathrm{C}$ dates were calibrated, and Oxcal v. 4.0.5 (Reimer et al., 2004; Bronk Ramsey, 2008) was

Table 1

${ }^{14} \mathrm{C}$ AMS dates $(2 \sigma)$ with calibrated and modeled ages (Oxcal v. 4.0.5; Reimer et al., 2004; Bronk Ramsey, 2008) for the sediment core taken in 1995 (composite depth). Calibrated ages are given in cal. yr BP and refer to AD 1950.

\begin{tabular}{llllr}
\hline Depth [cmblf] & Material & USGS-WW\# & AMS ${ }^{14} \mathrm{C}$ yr BP/AD & Cal. yr BP \\
\hline 0 & Sediment & 2676 & $330 \pm 50$ & 12 \\
21 & Pb-increase & & ca AD 1890 & 138 \\
70 & Sediment & 2677 & $1130 \pm 40$ & $551-321$ \\
$172-180$ & Charcoal & 2673 & $1310 \pm 50$ & $1290-1180$ \\
190 & Sediment & 2678 & $1860 \pm 50$ & $1267-1078$ \\
280 & Sediment & 2679 & $2330 \pm 50$ & $1815-1651$ \\
$372-380$ & Charcoal & 2106 & $2230 \pm 40$ & $2330-2160$ \\
380 & Sediment & 2680 & $2970 \pm 40$ & $2457-2320$ \\
$472-480$ & Low charcoal & 2674 & $3130 \pm 60$ & $3440-3260$ \\
480 & Sediment & 2681 & $3500 \pm 40$ & $3146-2961$ \\
$570-580$ & Charcoal & 2107 & $3430 \pm 40$ & $3820-3615$ \\
581 & Sediment & 2682 & $4230 \pm 40$ & $3905-3649$ \\
\hline
\end{tabular}

used to establish an age model. The age-depth relationships suggest that sedimentation was continuous. An indication of the presence of a reservoir effect is the apparent ${ }^{14} \mathrm{C}$ age at the sediment surface ( $330 \pm 50$ years), which must be considered as a minimum value, because of an addition of bomb ${ }^{14} \mathrm{C}$. The relation of ${ }^{14} \mathrm{C}$ ages vs. depth (Table 1 ) and the comparison of sediment versus charcoal ${ }^{14} \mathrm{C}$ ages (Fig. 3a) indicate a substantial reservoir correction of ca $600{ }^{14} \mathrm{C}$ years. The best estimate of the reservoir correction has been obtained in an iterative procedure. The reservoir age was varied (constant for all sediment samples), and depth-age models were generated in OxCal v. 4.0, using the P_Sequence option. The reservoir age value that resulted in the correctly calculated age for the sediment top (AD 1995) was selected as optimal (640 years).

Using this value, calibrated age ranges of the sediment and the charcoal samples are shown in Fig. 3b. Within the error range the ages agree well; one charcoal sample dates older than the sediment, which may be explained by the 'old wood' effect, i.e., the charcoal may have been deposited for some centuries on the ground surrounding the lake. All ages are given in calendar years before present (cal. years BP), where "present" is AD 1950.
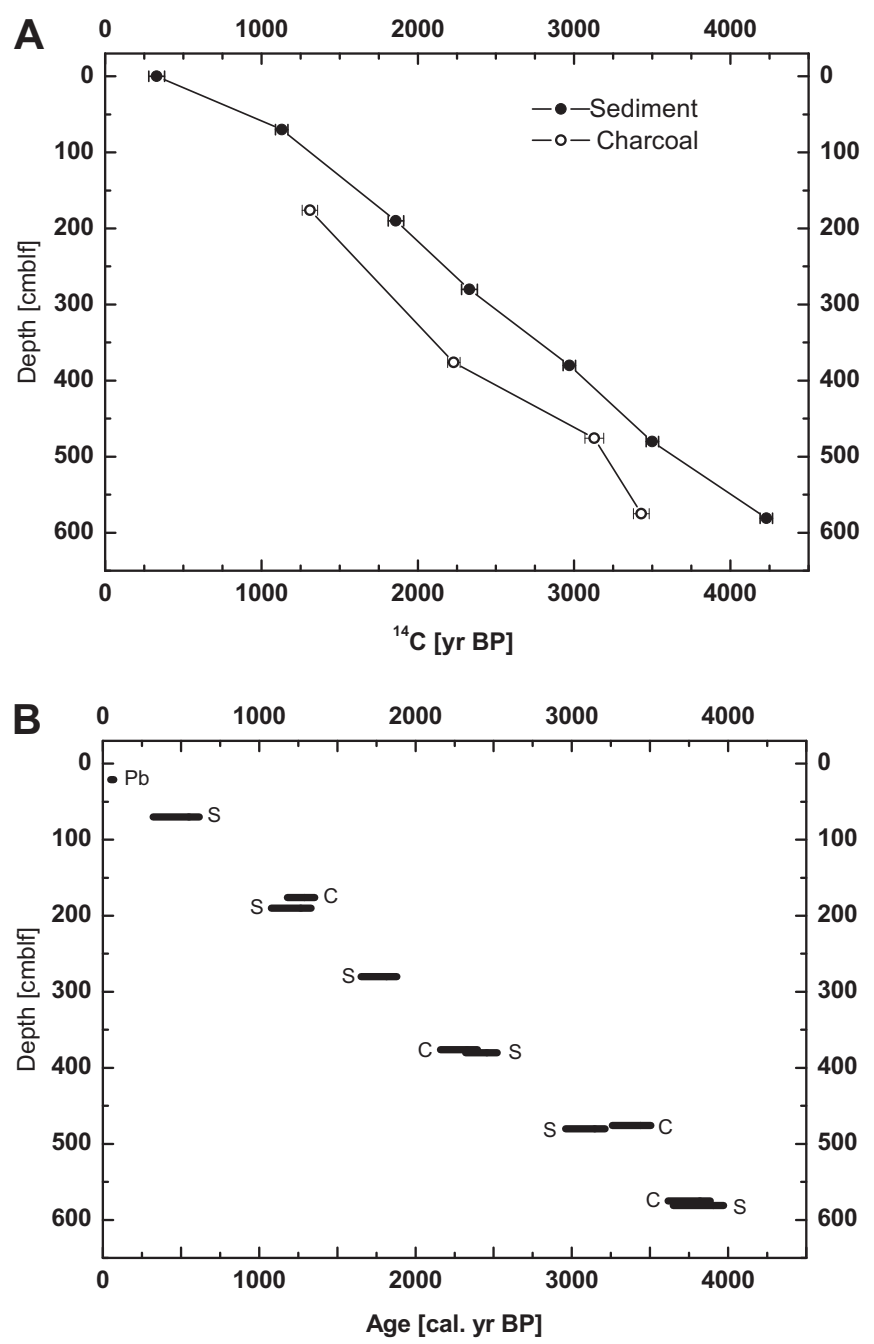

Fig. 3. (A) Comparison of sediment depth versus charcoal ${ }^{14} \mathrm{C}$ ages indicates a substantial reservoir correction of ca $600{ }^{14} \mathrm{C}$ years. (B) Age model of core based on bulk sediment (S) and charcoal (C) data calculated by OxCal v. 4.0, using the P_Sequence option. All ages are given in cal. yr BP and refer to AD 1950. Error ranges are 1-sigma. 
4.2. Eolian input indicators: magnetic susceptibility, aluminum, iron and Fabaeformiscandona rawsoni

Magnetic susceptibility in lake sediments largely depends on the abundance, grain-size and mineralogy of magnetic particles, mostly iron-bearing minerals such as detrital magnetite, maghemite or iron-sulfides. It is thus used as a proxy for detrital clastic material (e. g., Dearing et al., 1986; Dearing, 1991; Sprowl and Banerjee, 1993; Dean et al., 1996; Oldfield et al., 2002) although magnetic minerals also can form through bacteria and other diagenetic processes in lake sediments (e.g., Dearing, 1999; Oldfield and Wu, 2000; Nowaczyk, 2001; Geiss et al., 2004), and some iron-bearing minerals can be altered during chemical wethering, which can significantly change magnetic properties (e.g., Rosenbaum and Reynolds, 2004). Geiss et al. (2003) investigated four lakes along the prairie-forest ecotone in Minnesota and found that the sediment-magnetic properties of these lakes reflect changes in vegetation, erosional input or dilution of the detrital component by organic matter, degree of reductive dissolution, and the neoformation of magnetic minerals through magnetotactic bacteria (e.g., Moskowitz et al., 1989; Bazylinski, 1996). Variations in magnetic susceptibility can record variations in eolian or detrital input (Keen and Shane, 1990; Dean, 1997; Geiss et al., 2004; Rosenbaum and Heil, 2009) but in many cases the eolian signal is influenced by postdepositional dissolution of detrital iron-oxide minerals.

At Pickerel Lake the cycles shown in magnetic susceptibility are partially caused by dilution of eolian input through diamagnetic organic material, which is shown through a negative correlation between magnetic susceptibility and organic carbon content $(r=0.603)$. Yet, magnetic susceptibility varies by an order of a magnitude, whereas the contents in organic carbon vary by only about $50 \%$. We exclude lake level variations as the cause of the observed cycles, because the abundance of littoral ostracodes does not change proportionally with magnetic susceptibility.

Although absolute values for magnetic susceptibility are rather low and vary between 3 and $23 \times 10^{-6} \mathrm{SI}$, the structure of their cycles is distinctive (Figs. 2, 4-7). Values start to increase rather abruptly, and peak about 3250, 2700, 2150, 1600-1400, 1000-600, and 150 cal. yr BP. The older three cycles are characterized by welldefined peaks, and recent cycles, except the last, show broader peaks or multiple peaks. In between major peaks, secondary peaks reach only half the maximum amplitudes. The periodicities of the cycles range from 400 to 700 years, with an average of 600 years. Periodicities were determined by wavelet analysis (Prokoph and Barthelmes, 1996; Torrence and Compo, 1998; http://atoc. colorado.edu/research/wavelets/) using the Mortlet function (Fig. 4). The wavelet transform has the advantage over other transforms (e.g., various Fourier transforms) because it can be used to analyze nonstationary data, i.e., data that may contain periodic signals but these signals may vary in both frequency and amplitude with time. The wavelet analysis of the magnetic susceptibility data has the greatest power in the 512- to 1024-year periodicity band (Fig. 4b), demonstrating the strength of the 400-700-year cycles. The global wavelet power spectrum (Fig. 4c) shows that the ca 512year periodicity has by far the greatest power (variance) and is above the $95 \%$ confidence level. The 512-year spectral band also had the greatest power in varve thickness in sediments from Elk Lake for the last 1500 years (Dean et al., 2002). The Nyquist frequency (Davis, 1973) dictates that the sample record should be at least two times the longest period ( 700 years) or greater than 1500 years; our record contains six cycles in about 4000 years. The magnetic susceptibility cycles are accompanied by cycles with lower amplitudes in major elements and are best preserved in MAR values, such as those for aluminum ( $\mathrm{Al}$ ) and iron (Fe), with Al MAR varying between 7 and $25 \mathrm{~g} \mathrm{~m}^{-2} \mathrm{yr}^{-1}$, and Fe MAR reaching values between
5 and $14 \mathrm{~g} \mathrm{~m}^{-2} \mathrm{yr}^{-1}$ (Fig. 5). Maxima in magnetic susceptibility are accompanied by maxima in aluminum, also a dust indicator (e.g. Dean, 1993), iron, and also by maxima in abundance of the benthic ostracode F. rawsoni of up to 0.35 valves $\mathrm{g}^{-1}$ (Fig. 5; Schwalb, 2003). F. rawsoni is an eurytopic prairie-lake species that lives in both permanent and ephemeral, saline to fresh-water lakes and is indicative of windy and dry conditions (Delorme, 1989). Today, this species has not been caught alive in the lake (E. Ito, personal communication, 2009). A preliminary analysis of samples from high versus low susceptibility periods in Pickerel Lake suggests that Stephanodiscus and Cyclostephanos species are more abundant in the high susceptibility units. This suggests higher concentrations of phosphorus, likely driven by long periods of isothermal mixing during years with cool spring conditions (e.g. Bradbury, 1988).

The good correlation between magnetic susceptibility and MAR of detrital Aluminum as well as other indicators of drought strongly suggests that cyclic input of eolian sediment combined with drought-related postdepositional processes controls the magnetic susceptibility variations at Pickerel Lake.

\subsection{Lake productivity indicators: organic carbon, $\mathrm{CaCO}_{3}$, Candona ohioensis, phosphorus and $\delta^{13} \mathrm{C}$ of calcite}

Periods characterized by maxima in $\mathrm{OC}, \mathrm{CaCO}_{3}$, phosphorus $(\mathrm{P})$, and $\delta^{13} \mathrm{C}$ of calcite (Fig. 6) are interpreted as periods of maximum productivity. During more productive phases, photosynthetic activity increases. P, probably entering the lake mostly with ground water, is fixed, and ${ }^{12} \mathrm{C}$ is preferentially removed by algae. The remaining DIC pool is consequently enriched in ${ }^{13} \mathrm{C}$, the formation of endogenic carbonate and incorporation of ${ }^{13} \mathrm{C}$ increases, $\delta^{13} \mathrm{C}_{\text {calcite }}$ shifts to higher values, and $\mathrm{P}$ and $\mathrm{OC}$ are transferred to the sediments after algae die off. The antithetic relation between eolian indicators (e.g., magnetic susceptibility) and productivity indicators in the Pickerel Lake record is illustrated by the negative correlation between magnetic susceptibility and OC (Fig. 6), with a correlation coefficient of -0.603 . This suggests that calmer and wetter periods with increased photosynthetic productivity in the surface waters alternate with periods with maxima in eolian input. Both $\mathrm{CaCO}_{3}$ and $\mathrm{OC}$ contents vary from about 4 to $30 \%$ and 6 to $45 \%$, respectively, variations of about $50 \%$. Maxima in productivity, including more positive

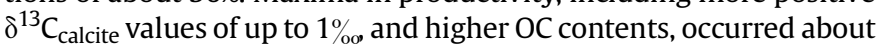
$3600-3400,3000,2400,1900-1700,1300-1100$ and 500-300 cal. yr BP. Maxima in these productivity indicators are concurrent with maxima in abundance of C. ohioensis (Schwalb, 2003), and a minimum abundance of littoral ostracodes (Schwalb, 2003). C. ohioensis is a stenotypic species that is restricted to fresh waters (Palacios-Fest et al.,1994). Today it is the dominant species in Pickerel Lake (E. Ito, personal communication, 2009) indicating a dilute system. The ostracode assemblage suggests that high productivity is associated with high lake levels and fresh-water conditions.

\subsection{Climate swings of the last millennium and solar signature}

The last millennium is characterized by two maxima in eolian input indicators at 1000-600 and $150 \mathrm{cal}$. yr BP, which are separated by a productivity maximum between 500 and 300 cal. yr BP (Figs. 5 and 6). The period 1000-600 cal. yr BP encompasses the period of the MCA (e.g., Pfister et al., 1998; Broecker, 2001; Bradley et al., 2003; Trouet et al., 2009). It is followed by a period of low magnetic susceptibility between 600 and 200 cal. yr BP indicating a low influx of eolian dust (Fig. 7) and contemporaneous with the LIA (e.g., Bradley and Jones, 1993; Pfister et al., 1998; Broecker, 2000; ca 1350-1850 AD). In the Pickerel Lake record, the LIA is characterized by stable lake levels and quiescent fresh-water conditions, as indicated by ostracodes, as well as by high 

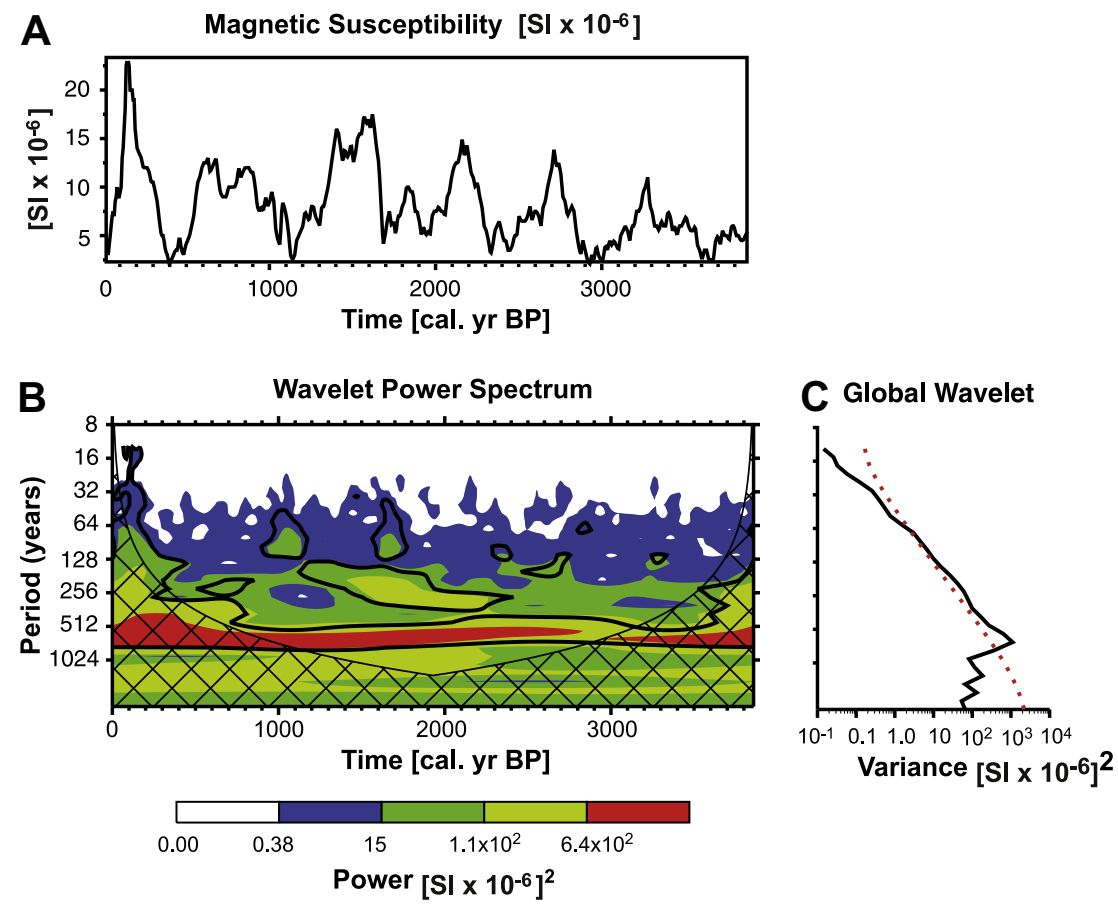

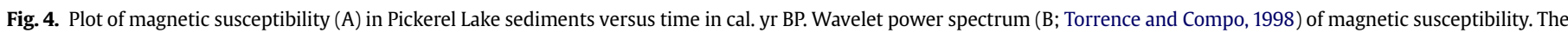

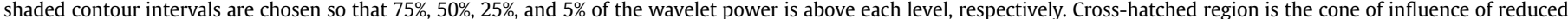

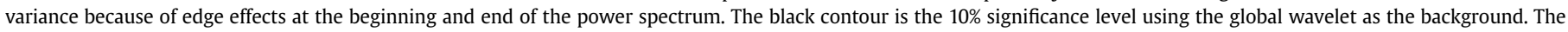

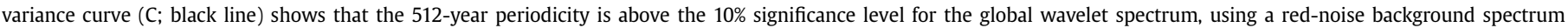
(dashed red line in C). (For interpretation of the references to colour in this figure legend, the reader is referred to the web version of this article.)

epilimnetic productivity (Fig. 6). The transition between the MCA and the LIA is marked by an abrupt increase in $\delta^{18} \mathrm{O}$ after $600 \mathrm{cal}$. yr BP exceeding $1 \%$ o (Fig. 7).

To test a possible relationship between proxies and solar forcing, we plotted data for magnetic susceptibility against residual (detrended) $\Delta^{14} \mathrm{C}$ (http://depts.washington.edu/qil/datasets) and $\delta^{18} \mathrm{O}$ signatures of calcite (Fig. 7). Times of the Maunder, Spörer, and Wolf sunspot minima (high $\Delta^{14} \mathrm{C}$ ) correspond approximately to positive spikes of about $1-1.4 \%$, shifting values of $\delta^{18} \mathrm{O}$ in calcite from about -6.9 to up to $-5.5 \%$ (Fig. 7), and low values of $\delta^{13} \mathrm{C}$ and OC content (Fig. 6). Because the major minerals identified by X-ray diffraction were calcite and quartz, with lesser amounts of dolomite and feldspar, we assume that most of the $\mathrm{CO}_{2}$ released during stable isotope analysis is derived from calcite. Interestingly, the correlation between OC and P breaks down during the LIA, suggesting that $P$ may not be the only nutrient limiting primary photosynthetic productivity. Two maxima in $\delta^{13} \mathrm{C}$ and OC occur between sunspot minima (Fig. 6), and values for P remain relatively low during the entire LIA. This may be related to relatively long periods of ice coverage and less vigorous mixture of the water column, reducing the entrainment of nutrient-rich bottom waters with surface waters. It may be that primary production in the lake was limited by another nutrient, such as nitrogen, during this period; recent studies suggest that nitrogen limitation is widespread in prairie lakes, especially during spring (Salm et al., 2009). We interpret higher values of $\delta^{18} \mathrm{O}$ to indicate decreases in lake surface water temperatures associated with decreases in epilimnetic photosynthetic productivity and OC burial (low OC and $\delta^{13} \mathrm{C}$ ). Today, Pickerel Lake water temperatures mainly reflect air temperatures (Niehus et al., 1999); the source of moisture, temperature of precipitation, and seasonality of precipitation play minor roles. Because we can exclude significant input of fluvial detrital carbonate, and because calcium concentrations in eolian sediments from the north-central USA are low (Muhs et al., 1997), we assume that all of the lake
$\mathrm{CaCO}_{3}$ is endogenic and precipitated from the epilimnetic waters. If all of the increase in $\delta^{18} \mathrm{O}_{\text {calcite }}$ during sun spot minima was the result of equilibrium precipitation of $\mathrm{CaCO}_{3}$ at different temperatures, then the increase of about $1-1.4 \%$ during sun spot minima would translate into a decrease in summer lake water temperature of up to $4-5{ }^{\circ} \mathrm{C}$ according to a increase of $0.24 \%$ for a decrease of $1{ }^{\circ} \mathrm{C}$ (McCrea, 1950; Stuiver, 1970; Dean and Stuiver, 1993). It is curious, however, that the solar signature is most pronounced during the LIA and is less visible before 2.3 cal. kyr BP. Overall, the solar signature in the Pickerel Lake record suggests that solar activity contributes significantly to centennial-scale climate variability in the northern GP under some mean states.

\section{Discussion}

\subsection{Late Holocene climate variability and forcing mechanisms}

Does the record from Pickerel Lake document a characteristic pattern of Late Holocene climate change? Are the climate signals we observe in this record typical of the northern GP, or are they expressions of global climate variability, and does the record provide a link between climate regimes? In order to explore these questions, we review evidence for Late Holocene centennial cyclic climate variability and the Late Holocene onset for climate cycles in North America and beyond, for teleconnections between the Pacific and Atlantic Oceans, and for possible origins, mechanisms and triggers of climate variability.

\subsection{Late Holocene climate variability in North America}

Proxy data from the Pickerel Lake record show distinct centennial-scale cycles during the last 4000 years of dry windy conditions that alternate with moister and less windy periods. We interpret the dry windy phases as a consequence of strong westerly 


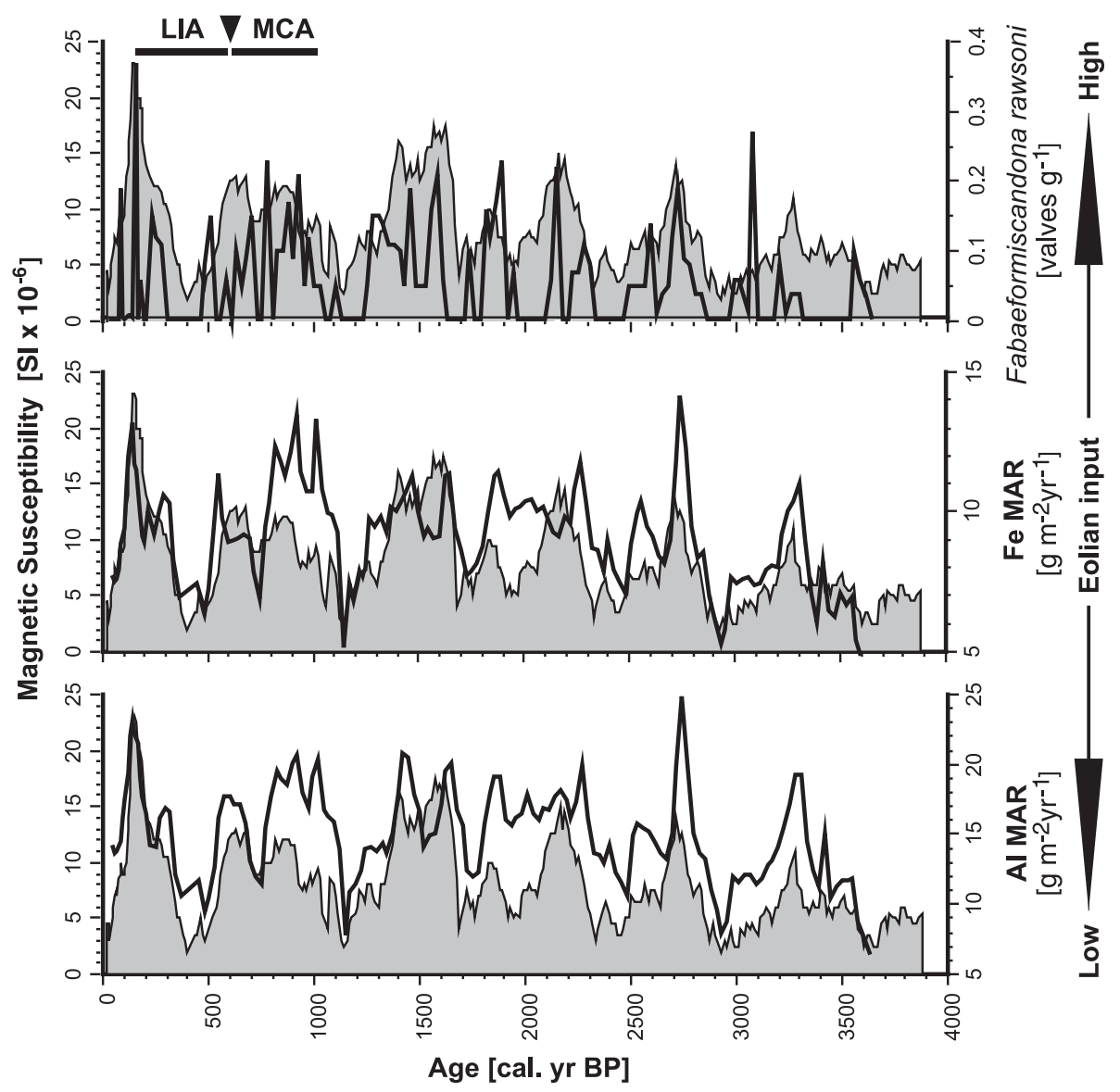

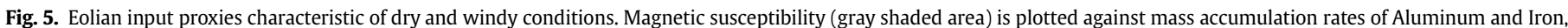

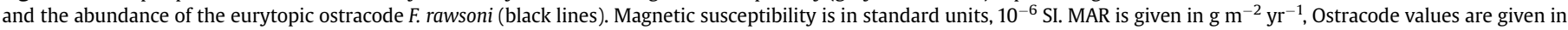
valves per $g$ of wet sediment. LIA and MCA denote the Little Ice Age and the Medieval Climate Anomaly.

winds. These cycles vary in length between 400 and 700 years, with an average periodicity of 600 years. Our data are consistent with centennial-scale cyclic variations in drought frequency in the northern GP based on lacustrine ostracode shell $\mathrm{Mg} / \mathrm{Ca}$ ratios (Yu and Ito, 1999) that show statistically significant periodicities of 400, 200,130 and 100 yr Dean (2002) documented distinct 400-yr cycles in $\mathrm{Al}$ in varved sediments deposited over the last 1500 years in Elk Lake. The most recent cycle occurred during the LIA and the previous cycle occurred between 900 and 500 varve yrs (= cal. yr BP), which includes the MCA. The 900-500-yr 400-yr cycle was superimposed on five 84-yr cycles.

Centennial periodicities also are apparent in records from both the west and east coastal regions of North America. Foram assemblages from the Santa Barbara Basin off the coast of California suggest that a series of extreme cool events associated with glacial advance in the Pacific Northwest occurred at 2.2, 1.5 and $0.8 \mathrm{kyr}$ (Fisler and Hendy, 2008). The timing of these cold events seem to correlate with periods of increased westerly wind activity as suggested by the Pickerel Lake record. Cross-spectral analysis of $\mathrm{Sr} / \mathrm{Ca}$ from a Holocene stalagmite record from West Virginia in the eastern United States and an ice-rafted debris (IRD) record from the North Atlantic shows periodicities of 715 and 455 years (Springer et al., 2008). In this case, centennial-scale droughts are correlated to the last five North Atlantic Ocean IRD episodes.

Strong multi-decadal periodicities are evident in some other GP records. For example, Brown et al. (2005) found fire cycles in Kettle Lake, North Dakota with a periodicity of about 160 years. Shapley et al. (2005) identified a recurrence frequency of pluvial periods of approximately 140-160 years during the Late Holocene, based on tree rings, lake sediments, and ancient shorelines in the Waubay Lake chain in northeastern South Dakota, a watershed that includes Pickerel and Enemy Swim Lakes. In our proxy data from Pickerel Lake, however, we do not see evidence for these shorter periodicities (Figs. 4-6).

Two of the most recent climate swings in this centennial pacing are the MCA (see Graham et al., 2007 and references therein) and the LIA, which are expressed in the Pickerel record as a magnetic susceptibility maximum (MCA) and a minimum (LIA), respectively. In Pickerel Lake, eolian indicators suggest increased westerly wind activity between about 1000 and 600 cal. yr BP. This correlates well with results from Elk Lake, where increases in both magnetic susceptibility and abundances of the diatom species Aulacoseira between 1000 and 700 cal. yr BP suggest an increase in windborne clastic material and associated wind-induced turbulence of the water column (Bradbury et al., 1993). Results from dune fields and loess deposits in the GP suggest extensive eolian activity in response to frequent severe drought between 1000 and $600 \mathrm{cal}$. yr BP (Sridhar et al., 2006; Miao et al., 2007; Seifert et al., 2009).

Several studies suggest that the climatic shift between the MCA and the LIA was large and rapid. This is evident in the Pickerel Lake record, which shows an abrupt increase in $\delta^{18} \mathrm{O}$ of calcite, suggesting abrupt cooling, coincident with the onset of a decrease in westerly wind activity after 600 cal. yr BP (Fig. 7). An abrupt decrease in mean drought intensity occurred about AD 1200 (750 cal. yr BP) in the GP as suggested from diatom evidence of Moon Lake (Laird et al., 1996b). Diatom data immediately to the 


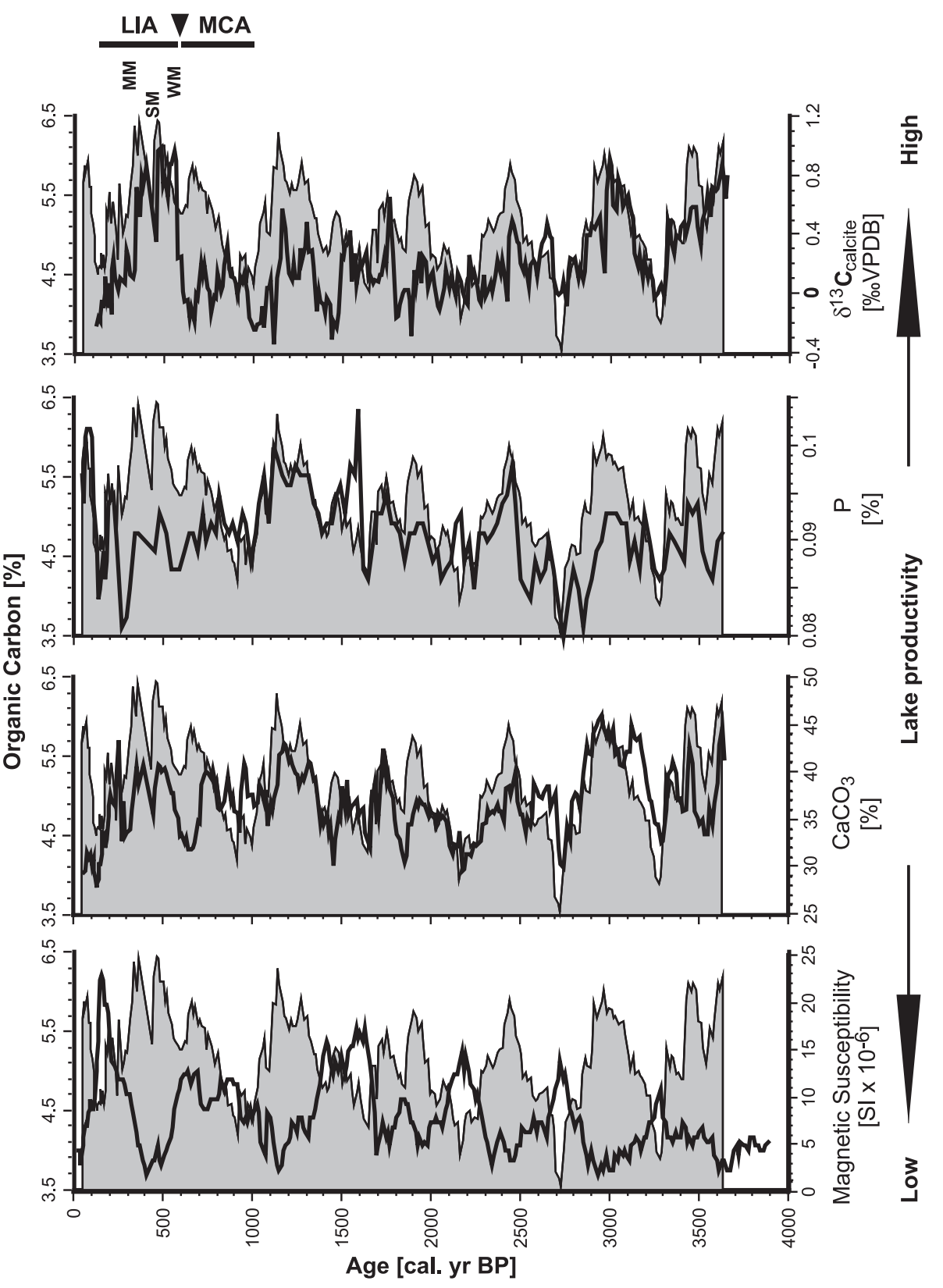

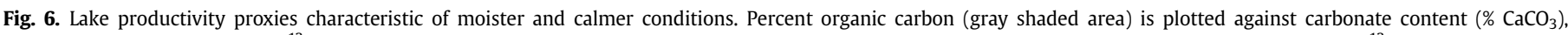

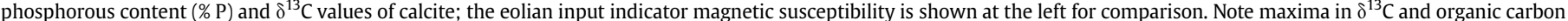
between sunspot minima Maunder (MM), Spörer (SM), Wolf (WM). LIA and MCA denote the Little Ice Age and the Medieval Climate Anomaly.

west in the Yellowstone region show an abrupt shift to cooler summers about that time (Bracht et al., 2008). The timing of the transition out of the MCA depicted by Graham et al. (2007) at about $1350 \mathrm{AD}$ (600 cal. yr BP) is closer to the timing observed in Pickerel Lake.

Several studies suggest that the rapid climate changes in western North America at the transition from the MCA to LIA may be associated with changes in ocean circulation, including changes in the tropical North Atlantic that took place 700 years ago (Black et al., 1999). Turney and Palmer (2007) suggest a step shift in the mean radiocarbon offset of the Southern Hemisphere, and Kuijpers et al. (2009) link paleoceanographic evidence from the North Atlantic subpolar gyre and NE Caribbean to a major, long-term change in ocean-atmosphere circulation modes around AD 1230 (720 cal. yr BP). This timing suggests that the termination of the MCA circulation mode may have occurred prior to the Wolf Solar
Minimum. None-the-less, in their overview of mid- to Late Holocene climate change, Wanner et al. (2008) conclude that the causes and spatial extent of the transition from the MCA to the LIA are still not entirely clear.

Regional studies from the GP and adjoining regions are consistent with the inference of cooler and less windy conditions at the onset of the LIA in Pickerel Lake, as well as higher although variable effective moisture levels (Anderson, 1993; Bradbury et al., 1993; Dean, 1997, 2002). The Elk Lake records suggest that the LIA was much less windy than the mid-Holocene and the MCA (Anderson, 1993; Dean, 1997, 2002). Diatom evidence from Elk Lake (Bradbury and Dieterich-Rurup, 1993) suggests that LIA climate was not consistently cool and wet but also included some intervals of drought. Decreased fire-induced erosion and shorter periods of lake stratification in the Yellowstone region suggest cool-moist conditions during the LIA (Pierce et al., 2004; Whitlock et al., 2008). 


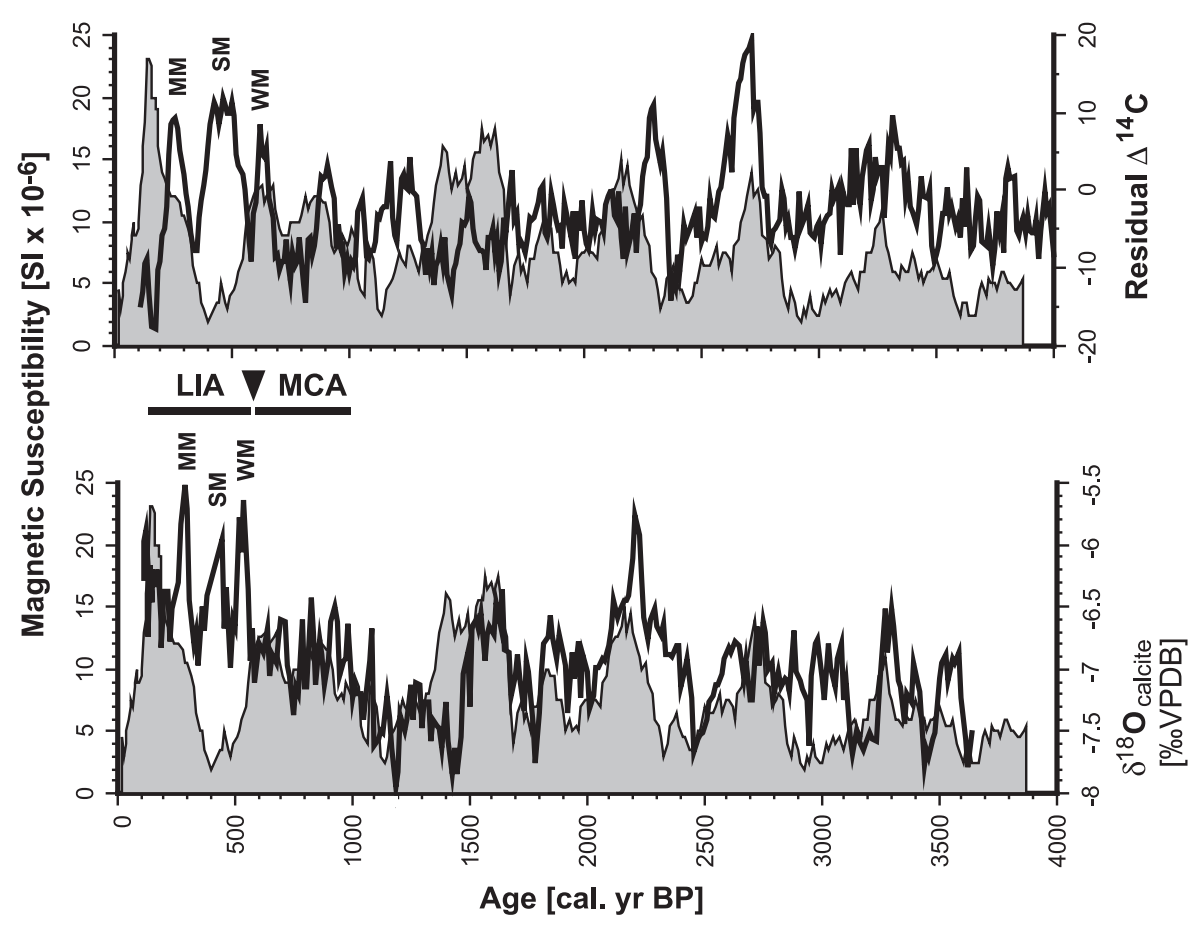

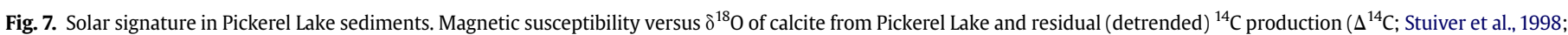

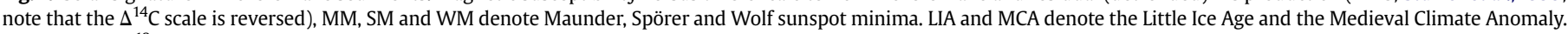
Note positive $\delta^{18} \mathrm{O}_{\text {calcite }}$ spikes corresponding to sunspot minima.

Composite temperature anomalies for North America, reconstructed from tree ring chronologies, suggest a temperature decrease of $<2{ }^{\circ} \mathrm{C}$ between 1570 and 1730 (380 and 220 cal. yr BP) and in the 19th century (Bradley and Jones, 1993). A tree ring based reconstruction of summer temperature suggests fluctuating LIA temperatures, with anomalies of $-1.5{ }^{\circ} \mathrm{C}$ at the Columbia Icefield, Alberta, Canada (Luckman et al., 1997). Trace elements and stable isotopes from lake records show evidence for the Maunder, Spörer, Wolf and Ort sunspot minima (e.g., Yu and Ito, 1999; Yu et al., 2002; Tian et al., 2006). These have been interpreted in terms of hydrological changes. A study by $\mathrm{Hu}$ et al. (2001) that deduced a temperature decrease of about $1.7{ }^{\circ} \mathrm{C}$ for Interior Alaska during the LIA using $\delta^{18} \mathrm{O}$ of endogenic carbonate and benthic ostracode shells. Our results from Pickerel Lake suggest that summer air temperatures may have decreased as much as by $4-5{ }^{\circ} \mathrm{C}$ during the LIA. If correct, this would suggest that LIA-cooling in North America was strongest in the northern GP.

Evidence of changes in continental climate in North America is coincident with changes in sea-surface temperature (SST), which would affect atmospheric circulation across the continent. For example, $\mathrm{Mg} / \mathrm{Ca}$ ratios in ostracodes from Chesapeake Bay suggests a temperature decrease of $2-4{ }^{\circ} \mathrm{C}$ during the LIA (Cronin et al., 2003). Planktic forams from the Gulf of Mexico similarly suggest a SST decrease of $2-2.5^{\circ} \mathrm{C}$ below modern (Richey et al., 2007). Coral $\delta^{18} \mathrm{O}$-data from the Caribbean also suggest that SST's were $2-4{ }^{\circ} \mathrm{C}$ cooler than present during the LIA (Winter et al., 2000). Planktic foraminiferal assemblages from the Santa Barbara Basin indicate that the coolest interval of the Holocene was coincident with the LIA (Fisler and Hendy, 2008).

Overall, these examples suggest that the continental interior of North America was sensitive to the LIA temperature decrease, which may be linked to SST anomalies and to decreases in solar activity during the LIA. Today, lake levels in northeastern South Dakota are relatively high. This is consistent with the modern low in magnetic susceptibility values, which in turn may be associated with decreased westerly wind strength and may be an expression of the clear observed trend towards higher frequencies of warm and moist air masses in the continental United States over the last half-century (Knight et al., 2008).

\subsection{Patterns of Late Holocene climate variability outside North America}

Multiple sites in the North Atlantic region are similar to Pickerel Lake in timing and periodicity of Late Holocene climate change. For example, Rousse et al. (2006) show evidence for 715, 240, 170 and $100 \mathrm{yr}$ periodicities in high-resolution magnetic analyses in marine sediments off North Iceland, more clearly expressed during the past 6 cal. kyr than in the previous period. Turney et al. (2005) found a 784-800-yr cycle in a data set based on a dendro-dated Irish bog tree population extending back 9000 cal. yr BP and provide evidence of major changes in Holocene surface moisture that reached maximum amplitudes after 5000 cal. yr BP. Björck et al. (2006) reconstructed humidity variations in sediments from a small crater lake in the Azores based mainly on magnetic susceptibility and $\mathrm{C} / \mathrm{N}$ records. The records show a shift at about 4000 cal. yr BP from a generally humid period to a generally more arid period with distinct cycles in humidity. Arid, low precipitation periods in the Azores often coincide with high IRD periods in the North Atlantic (Björck et al., 2006). The cooler/drier periods, which tend to correlate with the positive mode of the North Atlantic Oscillation, NAO, are also correlated with most of the westerly wind maxima in the Pickerel Lake eolian record. Phases of stronger westerly wind activity in the Pickerel Lake record also correlate with increases in SST's in the Nordic Seas, as documented by marine diatom records with, among others, 600- to 1000-year periodicities (N. Koç, personal communication, 2003; Berner et al., 2008). This suggests that climate variability observed over continental North America can be tracked across the Atlantic, and that westerly wind maxima correlate with the positive phase of the NAO. 
European patterns of moisture variation also show clear relationships with the Pickerel Lake record. Stacked Holocene peatland paleo-water table reconstructions from northern Britain (Charman et al., 2006) show wet phases at 3600, 2760 and 1600 that are highly correlated with mid-European lake high-stands cal. yr BP (Magny, 2004). Most of these wet intervals occurred during westerly wind maxima as shown by the Pickerel Lake record. Comparison with European glacier activity shows a less clear picture, because glacier activity depends on both precipitation and temperature. Glaciers on the Norwegian seaboard, for example, fed by winter precipitation, had Late Holocene glacier advances at 2900-2600 and 1200-800 (Matthews et al., 2005) that correlate with westerly wind maxima from Pickerel Lake.

\subsection{Onset of increased climate variability 4 cal. kyr BP}

\subsubsection{Climate regime change in North America}

Abundant evidence for a secular change at 4 cal. kyr BP to persistent moister conditions exists in the mid-continent of North America. The presence of the ostracode Darwinula stevensoni in Late Holocene sediments in Pickerel Lake indicates higher ground water input, likely driven by increased precipitation and ground water recharge (Schwalb and Dean, 1998). Moister conditions also are indicated by the replacement of prairie by forest at Elk Lake and Williams and Shingobee Lakes in Minnesota (e.g., Bradbury et al., 1993; Whitlock et al., 1993; Schwalb et al., 1995; Schwalb and Dean, 2002). Forman et al. (1995) show evidence for Late Holocene wet periods in the Central United States based on periods of eolian sand deposition and soil formation, and Arbogast and Wintle (2002) found evidence for the onset of peat accumulation in interdune areas in the eastern Upper Peninsula of Michigan at ca 4.4 cal. kyr BP. A secular increase in moisture at about 4 cal. kyr BP also is apparent in many other parts of North America, including the northwest (Spooner et al., 2002, 2003), the Southwest (Waters and Haynes, 2001; Menking and Anderson, 2003) New England (Huang et al., 2002), and Florida (Grimm et al., 2006). Thus, multiple lines of evidence indicated a pronounced change to moister conditions across North America at 4 cal. kyr BP.

The Pickerel Lake record also shows the onset of centennial cycles at 4 cal. kyr BP, and a few other western US records also suggest that the pattern of climate variability may have changed in the Late Holocene. Foram assemblages from the Santa Barbara Basin suggest that climatic variability increased at 4 cal. kyr (Fisler and Hendy, 2008). In the Northern Rocky Mountains, time-series analysis of a diatom-inferred drought record state indicates that quasi-periodic drought alternated with periods of less predictable drought starting around 4.5 cal. kyr BP (Stone and Fritz, 2006).

\subsubsection{Global rapid environmental change in the mid-Holocene}

A compilation of approximately 50 Holocene paleoclimate records shows a world-wide rapid environmental change around 4000 years ago from terrestrial and marine archives from North America, the North Atlantic, Northern Africa, the Arabian Sea and the Indian Ocean to China as well as ice cores from Greenland and the Tropics. Mayewski et al. (2004) suggests that the time period 4200-3800 cal. yr BP was one out of six Holocene periods of significant rapid climate change. Since that compilation, multiple recent studies show major changes at this time manifested by cooling of SSTs related to insolation forcing and a gradual transition towards a negative NAO (Andersen et al., 2004). Moros et al. (2006) suggested that increased drift ice input and directions in the northern North Atlantic may have played a role in the increase of cold intervals during the Late Holocene, such as the LIA. This was accompanied by cooling of continental areas (Bjune et al., 2005; Langdon and Barber, 2005) of the North Atlantic region and moisture changes in many tropical areas (Marchant and Hooghiemstra, 2004; Stevens et al., 2006; Metcalfe et al., 2007; Kröpelin et al., 2008; Van Breukelen et al., 2008). The onset of the Pickerel cycles at 4 cal. kyr BP also falls in the middle of profound cultural transitions in, for example, Mesopotamia (Weiss et al., 1993), Peru, Egypt, Japan, China, Scandinavia (Sandweiss et al., 1999; Brooks, 2006; Drysdale et al., 2006), thus emphasizing the significance of this transition for humans. In any case, multiple lines of evidence, including the onset of the cycles we observe in the Pickerel Lake record, suggest that there were major climate changes in the Northern Hemisphere and beyond beginning 4000 years ago.

\subsection{Causes of climate variability, teleconnections and climate mechanisms}

The timing of the onset of the Pickerel Lake cycles at around 4 cal. kyr BP indicates, that the decrease in Northern Hemisphere insolation and thus precession may have played a significant role. In addition, the LIA signature in the Pickerel Lake record hints that there is a solar component in driving climate variability, likely mediated by oceanic and atmospheric forcing. An open question is to what extent volcanic forcing may have interacted with the other components of the climate system and may have contributed to climate change.

\subsubsection{Sea-surface temperatures and continental drought}

There is now abundant evidence that climate variability and especially drought in central North America is related to SSTs in both the Atlantic and Pacific Oceans. In particular, many studies point to a prominent influence of the central equatorial Pacific as driving mechanism of North American droughts (e.g. Trenberth and Branstator, 1992; Trenberth and Branstator, 1992; Trenberth and Guillemot, 1996; Castro et al., 2001; Hoerling and Kumar, 2003; Seager et al., 2007; Herweijer et al., 2007; Cook et al., 2008). Schubert et al. (2004), analyzed ensemble climate simulations forced with reconstructed SSTs and demonstrated that the state of the tropical equatorial Pacific played an important role sustaining the 1930s drought. The prevailing La Niña-like SST-pattern caused a change in the northern hemisphere circulation patterns leading to drought over large parts of central and southern North America. The importance of this teleconnection pattern has been highlighted by Seager et al. (2005) for other periods with drought-like conditions in the 19th and 20th century. Herweijer et al. (2006) use the link between equatorial Pacific SSTs and precipitation over North America to reconstruct drought patterns in the last millennium. Teleconnections between the equatorial Pacific and North American climate at time scales characteristic of the PDO also have been suggested (e.g., MacDonald and Case, 2005; Stone and Fritz, 2006). These circulation modes may be persistent circulation regimes (Bradley et al., 2003), and even dominate the tropical Pacific for centuries (Wang and Tsonis, 2008). In addition, model results of summer circulation changes by Schubert et al. (2004) also show that cold Pacific SST anomalies generate a global-scale response in the upper troposphere that suppresses rainfall over the GP. For the "Dust Bowl" situation in the 1930s, Schubert et al. (2004) found, in addition to cool SSTs in the tropical Pacific, warm SSTs in the North Atlantic. In the lower troposphere, the response to the warm Atlantic SST anomalies was a cyclonic circulation anomaly positioned to suppress the supply of moisture entering the continent from the Gulf of Mexico. Wet conditions in the GP, on the other hand, are then related to an El Niño-like SST anomaly pattern with a warm equatorial Pacific, warm Indian Ocean, cool SSTs in the central North and South Pacific, and warm SSTs along the coasts of the Americas (Seager et al., 2005). 
For Pickerel Lake the following scenario is suggested: periods with strong westerly circulation, such as the MCA, were probably characterized by La Niña-like conditions, with cool tropical Pacific and warm Atlantic SSTs, which generated circulation patterns that blocked the penetration of moisture from the Gulf of Mexico into central North America, thus causing drought in the GP. Calm and relatively moist periods such as the LIA were caused by El Niño-like conditions, providing moisture from the Pacific.

\subsubsection{A solar connection}

A possible solar-climate link has been deduced from proxy evidence collected in the GP by several authors. Although irradiance variations are small in their direct effect, these effects can be amplified in the climate system (Haigh, 2001). Anderson (1992) and Dean et al. (1996) suggested a possible connection between surface winds, solar activity and the Earth's magnetic field from an association between ${ }^{14} \mathrm{C}$ in tree rings and a wind record preserved as changes in thickness of varved sediments in Elk Lake, Minnesota. Anderson $(1992,1993)$ presented evidence to show that oscillations in varve sediments in Elk Lake, with periods of about 200 years, that appear to be negatively correlated with $\Delta^{14} \mathrm{C}$ over the period from 7300 to 5300 varve years (mid-Holocene). Stuiver et al. (1991) concluded that century-scale variation in $\Delta^{14} \mathrm{C}$, with strongest spectral power of about 200 years (Suess solar cycle), are compatable with solar-magnetic forcing of primary cosmic rays. Tomson (1990) concluded that the 200 year periodicity in $\Delta^{14} \mathrm{C}$ record is beyond doubt. A possible solar forcing for century-scale drought frequency and climate shifts in the northern GP was suggested by Yu and Ito (1999), Yu et al. (2002) and Hu et al. (2003). Indeed, solar variability experiments have shown a distinct temperature response pattern in North America to changes in solar forcing (Cubasch et al., 1997).

Several researchers have suggested that centennial cycles may be caused by solar activity. The most prominent case that solar activity modulates climate on centennial-to-millennial time scales was provided by Bond et al. (2001), and the occurrence of centuryscale variability from ${ }^{10} \mathrm{Be}$ data from ice cores and ${ }^{14} \mathrm{C}$ data from tree rings (e.g. Stuiver and Braziunas, 1989; Sonett and Finney, 1990; Wanner et al., 2008; Knudsen et al., 2009). Dean and Schwalb (2000) reviewed evidence from lakes and sand dunes that centennial-scale cycles in aridity and eolian activity are the dominant feature of climate in the Northern GP of the United States over the past 2000 years, possibly with a solar-geomagnetic link. Several other authors have suggested that climate cycles at centennialscales are driven by solar forcing (Dergachev et al., 2000; Vasil'ev et al., 2000; Staubwasser et al., 2003; Springer et al., 2008; Knudsen et al., 2009). Usokin et al. (2008) underline the role of geomagnetic changes and solar activity and show that the regional effects of cosmic ray induced ionization due to geomagnetic changes may be comparable to or even dominate the solar signal at mid-latitudes on centennial-to-millennial time scales.

Magny (2004) used lake level data from central Europe as evidence for the role of solar activity in Holocene climate oscillations over the North Atlantic. Speleothem isotopic data from the North American Monsoon region of the southwestern United States (Asmerom et al., 2007) suggests a solar link for Holocene climate through changes in the Walker circulation and the PDO and ENSO systems of the tropical Pacific Ocean. Turney et al. (2005), on the other hand, argue that millennial and centennial cycles observed in North Atlantic climate are not coherent with changes in solar variability and are instead driven by nonlinear responses. More recently, however, Emile-Geay et al. (2007) have shown evidence for a statistically significant enhancement of the century-to-millennial-scale ENSO variability for even a moderate irradiance forcing. They concluded that periods of increased solar irradiance should be more La Niña-like and suggested that ENSO may plausibly have acted as a mediator between the Sun and the Earth's climate. This suggests that solar activity in concert with SSTs of the equatorial Pacific may indeed have played a major role in triggering the $400-700 \mathrm{yr}$ cycles we see in Pickerel Lake.

\subsubsection{Teleconnections}

The correlation between North American climate and Pacific SSTs shows the potential control of droughts by the equatorial Pacific. The timing of the strengthening of ENSO accompanied by a shift to greater climate variability after the Mid-Holocene (e.g. Shulmeister and Lees, 1995; Rodbell et al., 1999; Moy et al., 2002; Marchant and Hooghiemstra, 2004; Cane, 2005; Emile-Geay et al., 2007; Wang and Tsonis, 2008) further supports a link of North American climate change to the tropics. Another forcing mechanism is the Pacific Volcanic radiative forcing that may produce widespread cooling, as shown for the LIA (e.g., Crowley et al., 2008). A statistically significant tendency toward El Niñolike conditions in response to past volcanic radiative forcing was demonstrated by Mann et al. (2005). More recently, however, most volcanic eruptions were found to be too small to significantly affect ENSO statistics; only outsized volcanic eruptions are likely to generate an El Niño (Emile-Geay et al., 2008).

These teleconnections may have been prepared by the Late Holocene southward retreat of the ITCZ leading to a generally drier climate in Central America, as shown by Haug et al. (2001), Koutavas et al. (2006), Metcalfe et al. (2007). These authors suggest that the southward retreat of the ITCZ would have increased instability and amplified the potential for the westerly wind anomalies needed to initiate El Niño events. During North American droughts the ITCZ is shifted northward, whereas during the 1990s pluvial it was shifted southward (Seager et al., 2005).

Periods of westerly wind maxima as shown in the Pickerel Lake record seem to correlate with more humid periods in Central and Northern Europe as suggested by various proxy records (e.g., Magny, 2004; Matthews et al., 2005; Charman et al., 2006; Verschuren and Charman, 2008). For the MCA westerly wind maxima from Pickerel Lake correlate with results by Barber et al. (2000) and Graham et al. (2007) pointing to increased westerly winds and warmer winter temperatures over northern Europe during Medieval times. This suggests that the North Atlantic may react as a transmitter of the climate signal. Trouet et al. (2009), for example, demonstrate evidence for a persistent positive NAO mode dominating the MCA followed by a clear shift to weaker NAO conditions during the LIA, which was probably coupled to an intensified Atlantic Meridional Overturning Circulation (AMOC) during the MCA. Strong westerly winds could thus have contributed to the strengthening of AMOC.

Overall, the Pickerel Lake record provides evidence for the "atmospheric bridge" connecting the tropical Pacific and Atlantic Oceans at multi-decadal time scales as proposed by Latif (2001). This also underlines the role of wind shifts as a cause for abrupt climate change by changing the ocean circulation as suggested by Wunsch (2006).

\section{Conclusions}

Combined proxy evidence at decadal resolution from higher abundances of eolian input indicators, such as magnetic susceptibility, aluminum, iron and $F$. rawsoni are interpreted to reflect increased westerly wind activity and thus atmospheric circulation patterns that changed every 400-700 years and increased in strength with time. We observe alternations between windy and dry conditions centered around 3250, 2700, 2150, 1600-1400, 
1000-600 and 150 cal. yr BP, and calm and moister periods characterized by higher abundances of lake productivity indicators including $\mathrm{OC}, \mathrm{CaCO}_{3}, \mathrm{C}$. ohioensis, phosphorous and $\delta^{13} \mathrm{C}$ of lake marl at around about 3600-3400, 3000, 2400, 1900-1700, 1300-1100 and 500-300 cal. yr BP. The magnetic susceptibility data from Pickerel Lake sediments may provide an opportunity for higher resolution search for more direct climate signatures than biogenic and geochemical proxies.

The last millennium is characterized by two maxima in eolian input indicators, one at 1000-600, contemporary with the MCA, and the second at $150 \mathrm{cal}$. yr BP. These are separated by a lake productivity maximum between 500 and 300 cal. yr BP and variable environmental conditions, during the LIA. The transition between the MCA and the LIA is marked by an abrupt increase in $\delta^{18} \mathrm{O}_{\text {calcite }}$ after $600 \mathrm{cal}$. yr BP, correlative with the Wolf sunspot minimum. From $\delta^{18} \mathrm{O}_{\text {calcite, }}$, reconstructed temperature decreases up to $4-5{ }^{\circ} \mathrm{C}$ during the Maunder, Spörer and Wolf sunspot minima. This hints at a strong temperature response in the continental interior of the northern GP, ultimately linked to solar variation. The solar signature is most pronounced during the LIA and is less visible before $2.3 \mathrm{cal}$. kyr BP.

A literature review of information from proxy data suggests that the centennial cycles archived in Pickerel Lake document a characteristic pattern of Late Holocene climate with recurrent periods of enhanced wind activity and thus eolian transport as an expression of global climate variability in the north-central GP. In addition, the record may provide a link between climate regimes and teleconnection mechanisms between the Pacific and Atlantic Oceans. Periods with strong westerly circulation, such as the MCA, seem to correlate with La Niña-like conditions characterized by cool tropical Pacific and warm Atlantic SSTs. These conditions also correlate with the positive phase of the NAO and moister climate in Central and Northern Europe. Alternating calm and moister periods such as the LIA were caused by El Niño-like conditions, providing moisture from the Pacific.

The onset of the observable six centennial cycles at around 4 cal. kyr BP, accompanied by a return to a moister climate in North America, suggests that there were major changes in global atmospheric circulation patterns in the Northern Hemisphere beginning about 4000 years ago, which may have been driven by precession. The onset of the cycles is consistent with a more variable Late Holocene climate, as well as transformations in human societies in Europe and the Near East as provided by abundant evidence from a broad range of climate archives.

Overall, we propose that the centennial cycles originate from the tropical Pacific and are triggered by solar activity. This connection is further supported by the contemporary onset of the cycles and strengthening of ENSO during the Late Holocene associated with insolation conditions driven by precession. The cyclic pattern is then transferred into the atmosphere and transmitted by westerly winds into the North Atlantic realm where they strengthen the AMOC during periods of northern GP wind maxima. This consequently leads to moister climates in Central and Northern Europe. Thus, Pickerel Lake provides evidence for mechanisms for teleconnection patterns, underlining the role of wind shifts in climate change, as well as evidence for an atmospheric bridge between the different climate regimes of the tropical Pacific, the North Atlantic realm and the European continent.

\section{Acknowledgements}

This research was initially funded by DEKLIM, the German Climate Research Program (DEKLIM E: PROSIMUL III, FKZ 01 LD 003, A.S.) and the U.S. Geological Survey Global Change and Climate History and Earth Surface Dynamics Programs (W.E.D.). We thank Amy Myrbo and Anders Noren for support and discussions, and Dan Muhs, Lesleigh Anderson as well as two anonymous reviewers for very helpful comments on an earlier version of this paper. Cores are archived at LacCore (National Lacustrine Core Repository), Department of Geology and Geophysics, University of Minnesota - Twin Cities.

\section{References}

Anderson, R.Y., 1992. Possible connection between surface winds, solar activity and the Earth's magnetic field. Nature 358, 51-53.

Anderson, R.Y., 1993. The varve chronometer in Elk Lake: record of climatic variability and evidence for solar-geomagnetic- ${ }^{14} \mathrm{C}$-climate connection. In: Bradbury, J.P., Dean, W.E. (Eds.), Elk Lake, Minnesota: Evidence for Rapid Climate Change in the North-Central United States. Geological Society of America, Boulder, Colorado, Special Paper, vol. 276, pp. 45-67.

Anderson, R.Y., Dean, W.E., Bradbury, J.P., 1993. Elk Lake in perspective. In: Bradbury, J.P., Dean, W.E. (Eds.), Elk Lake, Minnesota: Evidence for Rapid Climate Change in the North-Central United States. Geological Society of America, Boulder, CO, USA Special paper, vol. 276, pp. 1-6.

Andersen, C., Koç, N., Jennings, A., Andrews, J.T., 2004. Nonuniform response of the major surface currents in the Nordic Seas to insolation forcing: implications for the Holocene climate variability. Paleoceanography 19, PA2003. doi:10.1029/ 2002PA000873.

Arbogast, A.F., Wintle, A.G., 2002. Widespread middle Holocene dune formation in the eastern Upper Peninsula of Michigan and the relationship to climate and outlet-controlled lake level. Geology 30 (1), 55-58.

Asmerom, Y., Polyak, V., Burns, S., Rassmussen, J., 2007. Solar forcing of Holocene climate: new insights from a speleothem record, southwestern United States. Geology 35 (1), 1-4.

Barber, K.E., Maddy, D., Rose, N., Stevenson, A.C., Stoneman, R., Thompson, R., 2000 Replicated proxy-climate signals over the last $2000 \mathrm{yr}$ from two distant UK peat bogs: new evidence for regional palaeoclimate teleconnections. Quaternary Science Reviews 19, 481-487.

Bazylinski, D.A., 1996. Controlled biomineralization of magnetic minerals by magnetotactic bacteria. Chemical Geology 132, 191-198.

Berner, K.S., Koç, N., Divine, D., Godtliebsen, F., Moros, M., 2008. A decadal-scale Holocene sea surface temperature record from the subpolar North Atlantic constructed using diatoms and statistics and its relation to other climate parameters. Paleoceanography 23, PA2210. doi:10.1029/2006PA001339.

Björck, S., Rittenour, T., Rosén, P., França, Z., Möller, P., Snowball, I., Wastegård, S Bennike, O., Kromer, B., 2006. A Holocene lacustrine record in the central North Atlantic: proxies for volcanic activity, short-term NAO mode variability, and long-term precipitation changes. Quaternary Science Reviews 25, 9-32.

Bjune, A.E., Bakke, J., Nesje, A., Birks, H.J.B., 2005. Holocene mean July temperature and winter precipitation in western Norway inferred from palynological and glaciological lake-sediment proxies. The Holocene 15 (2), 177-189.

Black, D.E., Peterson, L.C., Overpeck, J.T., Kaplan, A., Evans, M., Kashgarian, M., 1999 Eight centuries of North Atlantic Ocean-atmosphere variability. Science 286, 1709-1713.

Bond, G., Kromer, B., Beer, J., Muscheler, R., Evans, M.N., Showers, W., Hoffmann, S. Lotti-Bond, R., Hajdas, I., Bonani, G., 2001. Persistent solar influence on North Atlantic climate during the Holocene. Science 294, 2130-2136.

Bracht, B.B., Stone, J.R., Fritz, S.C., 2008. A diatom record of Late Holocene climate variation in the northern range of Yellowstone National Park, USA. Quaternary International 188, 149-155.

Bradbury, J.P., 1988. A climatic limnologic model of diatom succession for palaeolimnological interpretation of varved sediments at Elk Lake, Minnesota. Journal of Paleolimnology 1, 115-131.

Bradbury, J.P., Dieterich-Rurup, K.V., 1993. Holocene diatom paleolimnology of Elk Lake, Minnesota. In: Bradbury, J.P., Dean, W.E. (Eds.), Elk Lake, Minnesota: Evidence for Rapid Climate Change in the North-Central United States. Geological Society of America, Boulder, Colorado, Special Paper, vol. 276, pp. 215-237.

Bradbury, J.P., Dean, W.E., Anderson, R.Y., 1993. Holocene climatic and limnologic history of the north-central United States as recorded in the varved sediments of Elk Lake, Minnesota: a synthesis. In: Bradbury, J.P., Dean, W.E. (Eds.), Elk Lake, Minnesota: Evidence for Rapid Climate Change in the North-Central United States. Geological Society of America, Boulder, Colorado, Special Paper, vol. 276, pp. 309-328.

Bradley, R.S., Jones, P.D., 1993. 'Little Ice Age' summer temperature variations: their nature and relevance to recent global warming trends. The Holocene 3 (4), 367-376.

Bradley, R.S., Hughes, M.K., Diaz, H.F., 2003. Climate in Medieval times. Science 302, 404-405.

Briggs, P.H., 2002. The determination of forty elements in geological and botanical samples by inductively coupled plasma-atomic emission spectrometry. In: Taggart, J.E. (Ed.), Analytical Methods for Chemical Analyses of Geologic and Other Materials, pp. G1-G20. U.S. Geol. Survey Open-File Rept. 02-223.

Broecker, W.S., 2000. Was a change in thermohaline circulation responsible for the Little Ice Age? PNAS 97 (4), 1339-1342.

Broecker, W.S., 2001. Was the Medieval Warm Period global? Science 291 1497-1499. 
Bronk Ramsey, C., 2008. Deposition models for chronological records. Quaternary Science Reviews 27, 42-60.

Brooks, N., 2006. Cultural responses to aridity in the Middle Holocene and increased social complexity. Quaternary International 151, 29-49.

Brown, K.J., Clark, J.S., Grimm, E.C., Donovan, J.J., Mueller, P.G., Hansen, B.C.S Stefanova, I., 2005. Fire cycles in North American interior grasslands and their relation to prairie drought. PNAS 102 (25), 8865-8870.

Bryson, R.A., Hare, F.K., 1974. Climates of North America. In: Landsberg, H.E. (Ed.), World Survey of Climatology, vol. 11. Elsevier, New York, pp. 1-47.

Cane, M.A., 2005. The evolution of El Niño, past and future. Earth and Planetary Science Letters 230, 227-240.

Castro, C., McKee, T., Pielke, R., 2001. The relationship of the North American monsoon to tropical and North Pacific Sea surface temperatures as revealed by observational analyses. Journal of Climate 14, 4449-4473.

Charman, D.J., Blundell, A., Chiverrell, R.C., Hendon, D., Langdon, P.G., 2006 Compilation of non-annually resolved Holocene proxy climate records: stacked Holocene peatland lapaeo-water table reconstructions from northern Britain. Quaternary Science Reviews 25, 336-350.

Clark, J.S., Grimm, E.C., Donovan, J.J., Fritz, S.C., Engstrom, D.R., Almendinger, J.E., 2002. Drought cycles and landscape responses to past aridity on prairies of the Northern Great Plains, USA. Ecology 83 (3), 595-601.

Cole, J.E., Overpeck, J.T., Cook, E.R., 2002. Multiyear La Niña events and persistent drought in the contiguous United States. Geophysical Research Letters 29, 1647. doi:10.1029/2001GL013561.

Cook, E.R., Woodhouse, C.A., Eakin, C.M., Meko, D.M., Stahle, D.W., 2004. Long-term aridity changes in the western United States. Science 306, 1015-1018.

Cook, B.I., Miller, R.L., Seager, R., 2008. Dust and sea surface temperature forcing of the 1930s "Dust Bowl". Geophysical Research Letters 35, L08710. doi:10.1029/ 2008 GL033486.

Cronin, T.M., Dwyer, G.S., Kamiya, T., Schwede, S., Willard, D.A., 2003. Medieva Warm Period, Little Ice Age and 20th century temperature variability from Chesapeake Bay. Global and Planetary Change 36, 17-29.

Cubasch, U., Voss, R., Hegerl, G.C., Waszkewitz, J., Crowley, T.J., 1997. Simulation of the influence of solar radiation on the global climate with an ocean-atmosphere general circulation model. Climate Dynamics 13, 757-767.

Crowley, T.J., Zielinski, G., Vinther, B., Udisti, R., Kreutz, K., Cole-Dai, J., Castellano, E. 2008. Volcanism and the Little Ice Age. PAGES News 16 (2), 22-23.

Davis, J.C., 1973. Statistics and Data Analysis in Geology. John Wiley and Sons, 550 pp.

Dean, W.E., 1993. Physical properties, mineralogy, and geochemistry of Holocene varved sediments from Elk Lake, Minnesota. In: Bradbury, J.P., Dean, W.E. (Eds.) Elk Lake, Minnesota: Evidence for Rapid Climate Change in the North-Centra United States. Geological Society of America, Boulder, CO, Special Paper 276, pp. 135-158.

Dean, W.E., 1997. Rates, timing, and cyclicity of Holocene eolian activity in northcentral United States: evidence from varved lake sediments. Geology 25 $331-334$.

Dean, W.E., 2002. A 1500-year record of climatic and environmental change in Elk Lake, Clearwater County, Minnesota II: geochemistry, mineralogy, and stable isotopes. Journal of Paleolimnology 27, 301-319.

Dean, W.E., Stuiver, M.,1993. Stable carbon and oxygen studies of the sediments of Elk Lake, Minnesota. In: Bradbury, J.P., Dean, W.E. (Eds.), Elk Lake, Minnesota: Evidence for Rapid Climate Change in the North-Central United States. Geologica Society of America, Boulder, Colorado, Special Paper, vol. 276, pp. 163-180.

Dean, W.E., Schwalb, A., 2000. Holocene environmental and climatic change in the northern Great Plains as recorded in the geochemistry of sediments in Pickerel Lake, South Dakota. Quaternary International 67, 5-20.

Dean, W.E., Ahlbrandt, T.S., Anderson, R.Y., Bradbury, J.P., 1996. Regional aridity in North America during the middle Holocene. The Holocene 6, 145-155.

Dean, W., Anderson, R., Bradbury, J.P., Anderson, D., 2002. A 1500-year record of climatic and environmental change in Elk Lake, Minnesota I: varve thickness and gray-scale. Journal of Paleolimnology 27, 287-299.

Dearing, J.A., 1991. Erosion and land use. In: Berglund, B.E. (Ed.), The Cultura Landscape During 6000 years in Southern Sweden, pp. 283-292.

Dearing, J., 1999. Magnetic susceptibility. In: Walden, J., Oldfield, F., Smith. J.P. (Eds.) Environmental Magnetism: a Practical Guide. Technical Guide, 6. Quaternary Research Association, London, UK, pp. 35-62.

Dearing, J.A., Morton, R.I., Price, T.W., Foster, I.D.L., 1986. Tracing movement of topsoil by magnetic measurements: two case studies. Physics of the Earth and Planetary Interiors 42, 93-104.

Delorme, L.D., 1989. Methods in Quaternary ecology 7. Freshwater ostracodes. Geoscience Canada 16, 85-90.

Dergachev, V.A., Raspopov, O.M., Vasil'ev, S.S., 2000. Long-term variability of solar activity during the Holocene. Proc. 1st Solar \& Space Weather Euro conference, the Solar Cycle and Terrestrial Climate, Tenerife, Spain, 489-492.

Donovan, J.J., Grimm, E.C., 2007. Episodic struvite deposits in a Northern Great Plains flywaylake. Holocene 17, 1155-1170.

Donovan, J.J., Smith, A.J., Panek, V.A., Engstrom, D.R., Ito, E., 2002. Climate-driven hydrologic transients in lake sediment records: calibration of groundwate conditions using 20th Century drought. Quaternary Science Reviews 21 (4) $605-624$.

Drysdale, R., Zanchetta, G., Hellstrom, J., Maas, R., Fallick, A., Pickett, M., Cartwright, I., Piccini, L., 2006. Late Holocene drought responsible for the collapse of Old World civilizations is recorded in an Italian cave flowstone. Geology 34 (2), 101-104.
Emile-Geay, J., Cane, M., Seager, R., Kaplan, A., Almasi, P., 2007. El Niño as a mediator of the solar influence on climate. Paleoceanography 22, PA3210. doi:10.1029/ 2006PA001304

Emile-Geay, J., Seager, R., Cane, M.A., Cook, E.R., Haug, G.H., 2008. Volcanoes and ENSO over the past millennium. Journal of Climate 21, 3134-3148. doi:10.1175/ 2007JCLI1884.1.

Engleman, E.E., Jackson, L.L., Norton, D.R., Fischer, A.G., 1985. Determination of carbonate carbon in geological materials by coulometric titration. Chemical Geology 53, 125-128.

Fisler, J., Hendy, I.L., 2008. California current system response to Late Holocene climate cooling in southern California. Geophysical Research Letters 35, L09702. doi:10.1029/2008GL033902.

Forman, S.L., Oglesby, R., Markgraf, V., Stafford, T., 1995. Paleoclimatic significance of Late Quaternary eolian deposition on the Piedmont and High Plains, Central United States. Global and Planetary Change 11, 35-55.

Forman, S.L., Marín, L., Gomez, J., Pierson, J., 2008. Late Quaternary eolian sand depositional record for southwestern Kansas: landscape sensitivity to droughts. Palaeogeography, Palaeoclimatology, Palaeoecology 265, 107-120.

Fritz, S.C., Ito, E., Yu, Z., Laird, K., Engstrom, D.R., 2000. Hydrologic variation in the Northern Great Plains during the last two millennia. Quaternary Research 53. 175-184.

Fritz, S.C., Metcalfe, S.E., Dean, W.E., 2001. Holocene climate of the Americas inferred from paleolimnological records. In: Markgraf, V. (Ed.), Interhemispheric Climate Linkages. Academic Press, San Diego, pp. 241-263.

Fye, F.K., Stahle, D.W., Cook, E.R., 2003. Paleoclimatic analogs to twentieth-century moisture regimes across the United States. In: American Meteorological Society, pp. 901-909.

Geiss, C.E., Umbanhowar, C.E., Camill, P., Banerjee, S.K., 2003. Sediment magnetic properties reveal Holocene climate change along the Minnesota prairie-forest ecotone. Journal of Paleolimnology 30, 151-166.

Geiss, C.E., Banerjee, S.K., Camill, P., Umbanhowar, C.E., 2004. Sediment-magnetic signature of land-use and drought as recorded in Lake sediment from southcentral Minnesota, U.S.A. Quaternary Research 62, 117-125.

Graham, N.E., Hughes, M.K. Ammann, C.M., Cobb, K.M., Hoerling, M.P., Kennett, D.J. Kennett, J.P., Rein, B., Stott, L., Wigand, P.E., Xu, T., 2007. Tropical Pacific - midlatitude teleconnections in medieval times. Climatic Change. doi:10.1007/ s10584-007-9239-2.

Grimm, E.C., Watts, W.A., Jacobson Jr., G.L., Hansen, B.C.S., Almquist, H., Dieffenbacher-Krall, A.C., 2006. Evidence for warm wet Heinrich events in Florida. Quaternary Science Reviews 25, 2197-2211.

Haigh,J.D. 2001. Climate variability and the influence of the Sun. Science 294, 2109-2111.

Haug, G.H., Hughen, K.A., Sigman, D.M., Peterson, L.C., Röhl, U., 2001. Southward migration of the intertropical convergence zone through the Holocene. Science 293, 1304-1308

Haworth, E.Y., 1972. Diatom succession in a core from Pickerel Lake, Northeastern South Dakota. In: Geological Society of America Bulletin, vol. 83, pp. 157-172.

Herweijer, C., Seager, R., Cook, E.R., 2006. North American droughts of the mid-late nineteenth century: a history, simulation and implication for Medieval drought. The Holocene 16, 159-171.

Herweijer, C., Seager, R., Cook, E.R., Emile-Geay, J., 2007. North American droughts of the last millenium from a gridded network of tree-ring data. Journal of Climate, 1353-1376. doi:10.1175/JCLI4042.1.

Hoerling, M., Kumar, A., 2003. The perfect ocean for drought. Science 299, 691-694.

Hu, F.S., Ito, E., Brown, T.A., Curry, B., Engstrom, D.R., 2001. Pronounced climatic variations in Alaska during the last two millennia. Proceedings National Academy of Sciences 98 (19), 10552-10556.

Hu, F.S., Kaufman, D., Yoneji, S., Nelson, D., Shemesh, A., Huang, Y., Tian, J., Bond, G., Clegg, B., Brown, T., 2003. Cyclic variation and solar forcing of Holocene climate in the Alaskan Subarctic. Science 301, 1890-1893.

Huang, Y., Shuman, B., Wang, Y., Webb III, T., 2002. Hydrogen isotope ratios of palmitic acid in lacustrine sediments record late Quaternary climate variations. Geology 30 (12), 1103-1106.

Keen, K.L., Shane, L.C., 1990. A continuous record of eolian activity and vegetation change at Lake Ann, east-central Minnesota. In: Geological Society of America Bulletin, vol. 102, pp. 1646-1657.

Knight, D.B., Davis, R.E., Sheridan, S.C., Hondula, D.M., Sitka, L.J., Deaton, M., Lee, T. R., Gawtry, S.D., Stenger, P.J., Mazzei, F., Kenny, B.P., 2008. Increasing frequencies of warm and humid air masses over the conterminous United States from 1948 to 2005. Geophysical Research Letters 35, L10702. doi:10.1029/2008GL033697.

Knudsen, M.F., Riisager, P., Jacobsen, B.H., Muscheler, R., Snowball, I., Seidenkrantz, M.-S., 2009. Taking the pulse of the Sun during the Holocene by joint analysis of ${ }^{14} \mathrm{C}$ and ${ }^{10} \mathrm{Be}$. Geophysical Research Letters 36, L16701. doi:10.1029/2009GL039439.

Koutavas, A., deMenocal, P., Olive, G.C., Lynch-Stieglitz, J., 2006. Mid-Holocene El Niño-Southern Oscillation (ENSO) attenuation revealed by individual foraminifera in eastern tropical Pacific sediments. Geology 34 (12), 993-996.

Kröpelin, S., Verschuren, D., Lézine, A.-M., Eggermont, H., Cocquyt, C., Francus, P. Cazet, J.-P., Fagot, M., Rumes, B., Russell, J.M., Darius, F., Conley, D.J., Schuster, M., von Suchodoletz, H., Engstrom, D.R., 2008. Climate-driven Ecosystem succession in the Sahara: the past 6000 years. Science 320, 765-768.

Kuijpers, A., Malmgren, B.A., Seidenkrantz, M.-S., 2009. Termination of the Medieval Warm Period: linking subpolar and tropical N Atlantic circulation changes to ENSO. PAGES News 17 (2), 76-77. 
Laird, K.R., Fritz, S.C., Grimm, E.C., Mueller, P.G., 1996a. Century-scale paleoclimatic reconstruction from Moon Lake, a closed-basin lake in the northern Great Plains. Limnology and Oceanography 41, 890-902.

Laird, K.R., Fritz, S.C., Maasch, K.A., Cumming, B.F., 1996b. Greater drought intensity and frequency before AD 1200 in the Northern Great Plains, USA. Nature 384, $552-554$.

Laird, K.R., Cumming, B.F., Wunsam, S., Rusak, J.A., Oglesby, R.J., Fritz, S.C., Leavitt, P. R., 2003. Lake sediment record large-scale shifts in moisture regimes across the northern prairies of North America during the past two millennia. PNAS 100 (5), 2483-2488

Langdon, P.G., Barber, K.E., 2005. The climate of Scotland over the last 5000 years inferred from multiproxy peatland records: inter-site correlations and regional variability. Journal of Quaternary Science 20 (6), 549-566.

Latif, M., 2001. Tropical Pacific/Atlantic Ocean interactions at multi-decadal time scales. Geophysical Research Letters 28 (3), 539-542.

Luckman, B.H., Briffa, K.R., Jones, P.D., Schweingruber, F.H., 1997. Tree-ring based reconstruction of summer temperatures at the Columbia Icefield, Alberta, Canada, AD 1073-1983. Holocene 7 (4), 375-389.

MacDonald, G.M., Case, R.A., 2005. Variations in the Pacific Decadal Oscillation over the past millennium. Geophysical Research Letters 32, L08703. doi:10.1029/ 2005GL022478.

Magny, M., 2004. Holocene climatic variability as reflected by mid-European lakelevel fluctuations, and its probable impact on prehistoric human settlements. Quaternary International 113, 65-80.

Mann, M.E., Cane, M.A., Zebiak, S.E., Clement, A., 2005. Volcanic and solar forcing of the tropical Pacific over the past 1000 years. Jornal of Climate 18, 447-456.

Marchant, R., Hooghiemstra, H., 2004. Rapid environmental change in African and South American tropics around 4000 years before present: a review. EarthScience Reviews 66, 217-260.

Matthews, J.A., Berrisford, M.S., Quentin Dresser, P., Nesje, A., Dahl, S.O., Bjune, A.E. Bakke, J., Birks, H.J.B., Lie, Ø., Dumayne-Peaty, L., Barnett, C., 2005. Holocene glacier history of Bjørnbreen and climatic reconstruction in central Jotunheimen, Norway, based on proximal glaciofluvial stream-bank mires. Quaternary Science Reviews 24, 67-90.

Mayewski, P.A., Rohling, E.E., Stager, J.C., Karlen, W., Maasch, K.A., Meeker, L.D., Meyerson, E.A., Gasse, F., van Kreveld, S., Holmgren, K., Lee-Thorp, J., Rosqvist, G., Rack, F., Staubwasser, M., Schneider, R.R., Steig, E.J., 2004. Holocene climate variability. Quaternary Research 62, 243-255.

McCabe, G.J., Palecki, M.A., 2006. Multidecadal climate variability of global lands and oceans. International Journal of Climatology 26, 849-865.

McCabe, G.J., Palecki, M.A., Betancourt, J.L., 2004. Pacific and Atlantic Ocean influences on multidecadal drought frequency in the United States. PNAS 101 (12), 4136-4141.

McCrea, J.M., 1950. The isotopic chemistry of carbonates and a paleotemperature scale. Journal of Chemical Physics 18, 849-857.

Menking, K.M., Anderson, R.Y., 2003. Contribution of La Niña and El Niño to middle Holocene drought and Late Holocene moisture in the American Southwest. Geology 31 (11), 937-940.

Meltzer, D.J., 1999. Human response to middle Holocene (Altithermal) climates on the North American Great Plains. Quaternary Research 52, 404-416.

Metcalfe, S.E., Davies, S.J., Braisby, J.D., Leng, M.J., Newton, A.J., Terrett, N.L., O'Hara, S.L., 2007. Long and short-term change in the Pátzcuaro Basin, central Mexico. Palaeogeography, Palaeoclimatology, Palaeoecology 247, $272-295$.

Miao, X., Mason, J.A., Swinehart, J.B., Loope, D.B., Hanson, P.R., Goble, R.J., Liu, X., 2007. A 10,000 year record of dune activity, dust storms, and severe drought in the central Great Plains. Geology 35 (2), 119-122.

Moros, M., Andrews, J.T., Eberl, D.D., Jansen, E., 2006. Holocene history of drift ice in the northern North Atlantic: evidence for different spatial and temporal modes. Paleooceanography 21, PA2017. doi:10.1029/2005PA001214.

Moskowitz, B.M., Frankel, R.B., Bazylinski, D.A., Jannasch, H.W., Lovley, D.R., 1989. A comparison of magnetite particles produced anaerobically by magnetotactic and dissimilatory iron-reducing bacteria. Geophysical Research Letters 16, 665-668.

Moy, C.M., Seltzer, G.O., Rodbell, D.T., Anderson, D.M., 2002. Variability of El Niño/ Southern oscillation activity at millennial timescales during the Holocene epoch. Nature 420, 162-165.

Muhs, D.R., Stafford, T.W., Been, J., Mahan, S.A., Burdett, J., Skipp, G., Rowland, Z., 1997. Holocene eolian activity in the Minot dune field, North Dakota. Canadian Journal of Earth Sciences 34, 1442-1459.

Niehus, C.A., Vecchia, A.V., Thompson, R.F., 1999. Lake-Level Frequency Analysis for the Waubay Lakes Chain, Northeastern South Dakota Water-Resources Investigations Report 99-4122, 166 p., 2 pls

Nowaczyk, N.R., 2001. Logging of magnetic susceptibility. In: Last, W.M., Smol, J.P. (Eds.), Basin Analysis, Coring, and Chronological Techniques. Tracking Environmental Change Using Lake Sediments, vol. 1. Kluwer Academic Publishers, Dordrecht, Netherlands, pp. 155-170.

Oldfield, F., Wu, R., 2000. The magnetic properties of the recent sediments of Brothers Water, N.W. England. Journal of Paleolimnology 23, 165-174.

Oldfield, F., Wake, R., Boyle, J., Jones, R., Nolan, S., Gibbs, Z., Appleby, P., Fisher, E., Wolff, G., 2002. The late-Holocene history of Gormire Lake (NE England) and its catchment: a multiproxy reconstruction of past human impact. Holocene 13 (5), 677-690.

Overpeck, J., Webb, R., 2000. Nonglacial rapid climate events: past and future. PNAS 97 (4), 1335-1338
Palacios-Fest, M.R., Cohen, A.S., Anadón, P., 1994. Use of ostracods as paleoenvironmental tools in the interpretation of ancient lacustrine records. Revista Española de Paleontología 9, 145-164.

Pfister, C., Luterbacher, J., Schwarz-Zanetti, G., Wegmann, M., 1998. Winter air temperature variations in western Europe during the early and high middle ges (AD 750-1300). Holocene 8 (5), 535-552.

Pierce, J.L., Meyer, G.A., Jull, A.J.T., 2004. Fire-induced erosion and millennial-scale climate change in northern ponderosa pine forests. Nature 432, 87-90.

Prokoph, A., Barthelmes, F., 1996. Detection of nonstationarities in geological time series: wavelet transform of chaotic and cyclic sequences. Computers \& Geosciences 22, 1097-1108.

Reimer, P.J., Baillie, M.G.L., Bard, E., Bayliss, A., Beck, J.W., Bertrand, C.J.H., Blackwell, P.G., Buck, C.E., Burr, G.S., Cutler, K.B., Damon, P.E., Lawrence, R.E., Fairbanks, R.G., Friedrich, M., Guilderson, T.P., Hogg, A.G., Hughen, K.A. Kromer, B., McCormac, G., Manning, S., Bronk Ramsey, C., Reimer, R.W. Remmele, S., Southon, J.R., Stuiver, M., Talamo, S., Taylor, F.W., van der Plicht, J. Weyhenmeyer, C.E., 2004. INTCAL04 terrestrial radiocarbon age calibration, $0-26$ cal kyr BP. Radiocarbon 46 (3), 1029-1058.

Richey, J.N., Poore, R.Z., Flower, B.P., Quinn, T.M., 2007. 1400 yr multiproxy record of climate variability from the northern Gulf of Mexico. Geology 35 (5), 423-426.

Rodbell, D.T., Seltzer, G.O., Anderson, D.M., Abbott, M.B., Enfield, D.B., Newman, J.H., 1999. An 75,000-year record of El Niño-driven alluviation in Southwestern Ecuador. Science 283, 516-520.

Rosenbaum, J.R., Reynolds, R.L., 2004. Basis for paleoenvironmental interpretation of magnetic properties of sediment from Upper Klamath Lake (Oregon): effects of weathering and mineralogical sorting. Journal of Paleolimnology 31, 253-265.

Rosenbaum, J.G., Heil Jr., C.W., 2009. The glacial/deglacial history of sedimentation in Bear Lake, Utah and Idaho. In: Rosenbaum, J.G., Kaufman, D.S. (Eds.), Paleoenvironments of Bear Lake, Utah and Idaho, and Its Catchment. Geologica Society of America Bulletin, Colorado, Special Paper, vol. 450, pp. 247-261. doi:10.1130/2009.2450(11)

Rousse, S., Kissel, C., Laj, C., Eiríksson, J., Knudsen, K.-L., 2006. Holocene centennia to millennial-scale climatic variability: evidence from high-resolution magnetic analyses of the last $10 \mathrm{cal} \mathrm{kyr}$ off North Iceland (core MD99-2275). Earth and Planetary Science Letters 242, 390-405.

Salm, C.R., Saros, J.E., Fritz, S.C., Osburn, C.L., Reieneke, D.M., 2009. Phytoplankton productivity across prairie saline lakes of the Great Plains (USA): a step toward deciphering patterns through lake classification models. Canadian Journal of Fisheries and Aquatic Sciences 66, 1435-1448.

Sandweiss, D.H., Maasch, K.A., Anderson, D.G., 1999. Transitions in the mid-Holocene. Science 283, 499-500.

Schubert, S., Suarez, M., Pegion, P., Koster, R., Bacmeister, J., 2004. On the cause of the 1930s Dust Bowl. Nature 303, 1855-1859.

Schwalb, A., 2003. Lacustrine ostracodes as stable isotope recorders of Late-glacial and Holocene environmental dynamics and climate. Journal of Paleolimnology 29 (3), 265-351. D.G. Frey and E.S. Deevey Review 3.

Schwalb, A., Dean, W.E., 1998. Stable isotopes and sediments from Pickerel Lake South Dakota, USA: a 12 ky record of environmental changes. Journal of Paleolimnology 20, 15-30.

Schwalb, A., Dean, W.E., 2002. Reconstruction of hydrological changes and response to effective moisture variations from North-Central USA lake sediments. Quaternary Science Reviews 21, 1541-1554.

Schwalb, A., Locke, S.M., Dean, W.E., 1995. Ostracode $\delta^{18} \mathrm{O}$ and $\delta^{13} \mathrm{C}$ evidence of Holocene environmental changes in the sediments of two Minnesota lakes. Journal of Paleolimnology 14, 281-296.

Seager, R., Kushnir, Y., Herweijer, C., Naik, N., Miller, J., 2005. Modeling of tropical forcing of persistent droughts and pluvials over western North America. Journal of Climate 18, 4068-4091.

Seager, R., Ting, M., Held, I., Kushnir, Y., Lu, J., Vecchi, G., Huang, H.-P., Harnik, N., Leetmaa, A., Lau, N.-C., Li, C., Velez, J., Naik, N., 2007. Model projections of an imminent transition to a more arid climate in Southwestern North America. Science 316, 1181-1184.

Seifert, C.L., Cox, R.T., Forman, S.L., Foti, T.L., Wasklewicz, T.A., McColgan, A.T., 2009 Relict nebkhas (pimple mounds) record prolonged Late Holocene drought in the forested region of south-central United States. Quaternary Research 71, 329-339.

Shapley, M.D., Johnson, W.C., Engstrom, D.R., Osterkamp, W.R., 2005. Late-Holocene flooding and drought in the Northern Great Plains, USA, reconstructed from tree rings, lake sediments and ancient shorelines. Holocene 15, 29-41.

Shulmeister, J., Lees, B.G., 1995. Pollen evidence from tropical Australia for the onset of an ENSO-dominated climate at c. 4000 BP. Holocene 5 (1), 10-18.

Smith, A.J., 1991. Lacustrine ostracodes as hydrochemical indicators in Holocen lake records of the north-central United States. PhD thesis, Providence (RI) Brown University, $306 \mathrm{pp}$

Smith, A.J., Donovan, J.J., Ito, E., Engstrom, D.R., Panek, V.A., 2002. Climate-driven hydrologic transients in lake sediment records: multiproxy record of midHolocene drought. Quaternary Science Reviews 21, 625-646.

Sonett, C.P., Finney, S.A., 1990. The spectrum of radiocarbon. In: Philosophica transactions of the Royal Society of London. Series A, vol. 330, pp. 413-426.

Spooner, I.S., Mazzucchi, D., Osborn, G.D., Larocque, I., Gilbert, R., 2002. Reconstruction of Holocene vegetation and climate change, Iskut Region, northern British Columbia, Canada. Journal of Paleolimnology 28, 419-431.

Spooner, I.S., Barnes, S., Baltzer, K.B., Raeside, R., Osborn, G.D., Mazzucchia, D., 2003. The impact of air mass circulation dynamics on Late Holocene paleoclimate in northwestern North America. Quaternary International 108 (1), 77-83. 
Springer, G.S., Rowe, H.D., Hardt, B., Edwards, R.L., Cheng, H., 2008. Solar forcing of Holocene droughts in a stalagmite record from West Virginia in east-central North America. Geophysical Research Letters 35, L17703. doi:10.1029/2008GL034971.

Sprowl, D.R., Banerjee, S.K., 1993. Geologic implications of the Elk Lake paleomagnetic record. In: Bradbury, J.P., Dean, W.E. (Eds.), Elk Lake, Minnesota: Evidence for Rapid Climate Change in the North-Central United States. Geological Society of America Bulletin, Boulder, Colorado, Special Paper, vol. 276, pp. 159-162.

Sridhar, V., Loope, D.B., Swinehart, J.B., Mason, J.A., Oglesby, R.J., Rowe, C.M., 2006 Large wind shift on the Great Plains during the medieval warm period. Science 313, 345-347.

Staubwasser, M.F., Sirocko, F., Grootes, P., Segl, M., 2003. Climate change at the 4.2 ka BP termination of the Indus valley civilization and Holocene south Asian monsoon variability. Geophysical Research Letters 30 (8), 1425. doi:10.1029/ 2002GL016822.

Stevens, L.R., Ito, E., Schwalb, A., Wright Jr., H.E., 2006. Shift in the timing of atmospheric precipitation in the Zagros Mountains inferred from a multi-proxy record from Lake Mirabad, Iran. Quaternary Research 66, 494-500.

Stone, J.R., Fritz, S.C., 2006. Multidecadal drought and Holocene climate instability in the Rocky Mountains. Geology 34 (5), 409-412.

Stuiver, M., 1970. Oxygen and carbon isotope ratios of fresh-water carbonates as climatic indicators. Journal of Geophysical Research 75 (27), 5247-5257.

Stuiver, M., Braziunas, T.F., 1989. Atmospheric ${ }^{14} \mathrm{C}$ and century-scale solar oscillations. Nature 338, 405-408.

Stuiver, M., Craziunas, T.F., Becker, B., Kromer, B., 1991. Climatic, solar, oceanic, and geomagnetic influence on the Late-glacial and Holocene atmospheric ${ }^{14} \mathrm{C} /{ }^{12} \mathrm{C}$ change. Quaternary Research 35, 1-24.

Stuiver, M., Reimer, P.J., Bard, E., Beck, J.W., Burr, G.S., Hughen, K.A., Kromer, B., McCormac, G., van der Plicht, J., Spurk, M., 1998. INTCAL98 radiocarbon age calibration. Radiocarbon 40 (3), 1041-1083.

Tian, J., Nelson, D.M., Hu, F.S., 2006. Possible linkages of late-Holocene drought in the North American midcontinent to Pacific decadal oscillation and sola activity. Geophysical Research Letters 33, L23702,. doi:10.1029/2006GL02816.

Tomson, D.J., 1990. Time series analysis of Holocene climate data. In: Pecker, J.C. Runcorn, S.K. (Eds.), The Earth's Climatic and Variability of the Sun Over Recent Millennia: Geophysical, Astronomial, and Archeological Aspects. Philosophical Transaction of he Royal Society of London, vol. A330, pp. 601-616.

Torrence, C., Compo, G.P., 1998. A practical guide to wavelet analysis. In: Bulletin of the American Meteorological Society, 79, pp. 61-78.

Trenberth, K.E., Branstator, G., 1992. Issues in establishing causes of the 1988 drought over North America. Journal of Climate 5, 159-172.

Trenberth, K.E., Guillemot, C.J. 1996. Physical processes involved in the 1988 drought and 1993 floods in North America. Journal of Climate 9, 1288-1298.

Trouet, V., Esper, J., Graham, N.E., Baker, A., Scourse, J.D., Frank, D.C., Frank, D.C., 2009. Persistent positive North Atlantic oscillation mode dominated the medieval climate anomaly. Science $324,78-80$.

Turney, C., Baillie, M., Clemens, S., Brown, D., Palmer, J., Pilcher, J., Reimer, P., Leuschner, H.H., 2005. Testing solar forcing of pervasive Holocene climate cycles. Journal of Quaternary Science 20 (6), 511-518.

Turney, C.S.M., Palmer, J.G., 2007. Does the El Niño-Southern Oscillation control the interhemispheric radiocarbon offset? Quaternary Research 67, 174-180.

Usokin, I.G., Korte, M., Kovaltsov, G.A., 2008. Role of centennial geomagnetic changes in local ioization. Geophysical Research Letters 35, L05811. doi:10.1029/ 2007 GL033040.
Van Breukelen, M.R., Vonhof, H.B., Hellstrom, J.C., Wester, W.C.G., Kroon, D., 2008. Fossil dripwater in stalagmites reveals Holocene temperature and rainfall variation in Amazonia. Earth and Planetary Science Letters 275, 54-60.

Verschuren, D., Charman, D.J., 2008. Latitudinal linkages in late-Holocene moisture-balance variation. In: Battarbee, R.W., Binney, H.A. (Eds.), Natural Climate Variability and Global Warming: A Holocene Perspective, pp. $189-231$.

Vasil'ev, S.S., Dergachev, V.A., Raspopov, O.M., 1999. Sources of long-term variations in the radiocarbon concentration in the Earth's atmosphere. Geomagnetismn and Aeronomy 39 (6), 749-757.

Wang, G., Tsonis, A.A., 2008. On the variability of ENSO at millennial timescales. Geophysical Research Letters 35, L17702. doi:10.1029/2008GL035092.

Wanner, H., Beer, J., Bütikofer, J., Crowley, T., Cubasch, U., Flückiger, J., Goosse, H., Grosjean, M., Joos, F., Kaplan, J., Küttel, M., Müller, S.A., Prentice, I.C., Solomina, O., Stocker, T.F., Tarasov, P., Wagner, M., Widmann, M., 2008. Mid- to Late Holocene climate change: an overview. Quaternary Science Reviews 27, 1791-1828.

Waters, M.R., Haynes, C.V., 2001. Late Quaternary arroyo formation and climate change in the American Southwest. Geology 29 (5), 399-402.

Watts, W.A., Bright, R.C., 1968. Pollen, seed, and mollusk analysis of a sediment core from Pickerel Lake, northeastern South Dakota. In: Geological Society of America Bulletin, vol. 79, pp. 855-876.

Weiss, H., Courty, M.-A., Wetterstrom, W., Guichard, F., Senior, L., Meadow, R., Curnow, A., 1993. The genesis and collapse of third millennium north Mesopotamian civilization. Science 261, 995-1004.

Whitlock, C., Bartlein, P.J., Watts, W.A., 1993. Vegetation history of Elk Lake. In: Bradbury, J.P., Dean, W.E. (Eds.), Elk Lake, Minnesota: Evidence for Rapid Climate Change in the North-Central United States. Geological Society of America Bulletin, Boulder, Colorado, Special Paper, vol. 276, pp. $251-274$.

Whitlock, C.A., Dean, W., Rosenbaum, J., Stevens, L., Fritz, S., Bracht, B., Power, M., 2008. A 2650-yr record of ecological and hydrological change in Yellowstone's Northern Range derived from multiple proxies. Quaternary International 188, 126-138.

Winter, A., Ishioroshi, H., Watanabe, T., Oba, T., Christy, J., 2000. Caribbean sea surface temperatures: two-to-three degrees cooler than present during the Little Ice Age. Geophysical Research Letters 27 (20), 3365-3368.

Woodhouse, C.A., Overpeck, J.T., 1998. 2000 years of drought variability in the Central United States. In: Bulletin of the American Meteorological Society, vol. 79, pp. 2693-2714.

Wright Jr., H.E., 1967. A square-rod piston sampler for lake sediments. Journal of Sedimentary Petrology 37, 975-976.

Wright, H.E., 1976. The dynamic nature of Holocene vegetation - a problem in paleoclimatology, biogeography, and stratigraphic nomenclature. Quaternary Research 6, 581-596.

Wunsch, C., 2006. Abrupt climate change: an alternative view. Quaternary Research 65, 191-203.

Yu, Z.C., Ito, E., 1999. Possible solar forcing of century-scale drought frequency in the northern Great Plains. Geology 27, 263-266.

Yu, Z., Ito, E., Engstrom, D.R., Fritz, S.C., 2002. A 2100-year trace-element and stableisotope record at decadal resolution from Rice Lake in the Northern Great Plains, USA. Holocene 12 (5), 605-617. 